\title{
Review of the clavatus group of the lanternfly genus Pyrops (Hemiptera: Fulgoromorpha: Fulgoridae)
}

\author{
Jérôme CONSTANT ${ }^{1}$ \& Hong-Thai PHAM ${ }^{2}$ \\ ${ }^{1}$ Royal Belgian Institute of Natural Sciences, O.D. Phylogeny and Taxonomy, Entomology, \\ Vautier Street 29, B-1000 Brussels, Belgium. \\ ${ }^{2}$ Vietnam National Museum of Nature, Vietnam Academy of Science and Technology, \\ 18 Hoang Quoc Viet Street, Hanoi, Vietnam. \\ *Corresponding author: jerome.constant@naturalsciences.be \\ 2Email: phamthai@vnmn.vast.vn \\ ${ }^{1}$ urn:1sid:zoobank.org:author:6E6072A1-9415-4C8D-8E60-2504444DB290 \\ ${ }^{2}$ urn:1sid:zoobank.org:author:E34CB863-7E3B-4E8F-8738-B41C07D9F5F9
}

\begin{abstract}
The clavatus group of Pyrops Spinola, 1839 is reviewed and redefined. The new combination Pyrops atroalbus (Distant, 1918) comb. nov. is proposed, as atroalbus is reinstated as a full species from status of subspecies of Pyrops watanabei (Matsumura, 1913). Pyrops nigripennis (Chou \& Wang, 1985) and Pyrops clavatus mizunumai (Sato \& Nagai, 1994) are proposed as junior synonyms of P. clavatus (Westwood, 1839). The Philippine species P. polillensis (Baker, 1925) is removed from the group and not attributed to any of the currently defined species groups. Hence, the clavatus group is restricted to continental Southeast Asia and Taiwan and contains three species: P. atroalbus comb. nov., $P$. clavatus and $P$. watanabei. A key to the species of the group and illustrations of the male genitalia are provided. The intraspecific colour variation in the group is discussed and illustrated. The genus Pyrops is removed from the subfamily Fulgorinae and not attributed to any of the currently defined subfamilies of Fulgoridae.
\end{abstract}

Keywords. Lanternfly, Southeast Asia, Vietnam, Laos, Taiwan.

Constant J. \& Pham H.-T. 2017. Review of the clavatus group of the lanternfly genus Pyrops (Hemiptera: Fulgoromorpha: Fulgoridae). European Journal of Taxonomy 305: 1-26. https://doi.org/10.5852/ejt.2017.305

\section{Introduction}

The enigmatic species Pyrops atroalbus (Distant, 1918) comb. nov. was known from a single male specimen until we recently collected additional material in Central Vietnam. This led us to examine the type material and compare the male genitalia with those of Pyrops watanabei (Matsumura, 1913), P. clavatus clavatus (Westwood, 1839) and Pyrops clavatus mizunumai (Sato \& Nagai, 1994) as well as other characters. We concluded that the present nomenclature of the group is not correct and that accurate identification of the species in the group is challenging, if based on currently available literature. 
The first recognition of clavatus as forming a separate group within Pyrops (at the time mentioned as Hotinus Amyot \& Serville, 1843) is found in Walker (1858). He separated clavatus from all other species grouped together with Pyrops candelaria (Linnaeus, 1758) as type, the latter group being again separated into two subgroups.

Baker (1925) formally defined the clavatus group in Pyrops (at the time, clavata group in Fulgora Linnaeus, 1767 - see also International Commission on Zoological Nomenclature (1955) and Constant (2015)) for 3 species with clavate cephalic process: one from continental Southeast Asia, P. clavatus, and two from the Philippines, P. polillensis (Baker, 1925) and P. samaranus (Baker, 1925).

Metcalf (1947), in his catalogue of the family Fulgoridae, transferred all species of Pyrops, at that time included in Fulgora, to the genus Laternaria Linnaeus, 1764, and proposed the name Laternaria watanabei var. formosana Metcalf, 1947 to replace Laternaria watanabei var. apicalis (Kato, 1928), because of the preoccupation of the original name Fulgora watanabei apicalis Kato, 1928 by Fulgora apicalis Westwood, 1838 (currently Prolepta apicalis (Westwood, 1838) - see also Constant \& Alisto (2015: 9) for comprehensive nomenclatural information on the species).

Later in 1963, Lallemand added two taxa to the group ("cinquième groupe: Type clavata"), at the time under the genus name Fulgora (in contradiction with the decision of the International Commission on Zoological Nomenclature (1955) - see also Constant (2015: 2) for a review on the inconsistent use of the genus names Fulgora, Pyrops and Laternaria): P. watanabei (Matsumura, 1913) and P. watanabei atroalbus (Distant, 1918). The latter was treated as a subspecies of $P$. watanabei, and as a senior synonym of Laternaria watanabei var. formosanus Metcalf, 1947.

Nagai \& Porion (1996) transferred all species placed in Fulgora by Lallemand (1963), into Pyrops Spinola, 1839, following the decision of the International Commission on Zoological Nomenclature (1955). Liang (1998) changed the species epithets in Pyrops into masculine when necessary, but erroneously stated that he proposed new combinations. Nagai \& Porion (1996) listed in the "Group $V^{\prime}$ as defined by Lallemand (1963), with clavatus as type, the following four species: Pyrops clavatus (Westwood, 1839) with the subspecies P. clavatus mizunumai (Sato \& Nagai, 1994), P. nigripennis (Chou \& Wang, 1985), P. polillensis (Baker, 1925) with P. samaranus (Baker, 1925) proposed as a junior synonym, and P. watanabei (Matsumura, 1913) with the subspecies P. watanabei atroalbus (Distant, 1918). Nagai \& Porion (1996) also mentioned that the sketch in the description of P. nigripennnis in Chou et al. (1985) closely resembles $P$. clavatus.

The present paper aims to solve several long-standing issues in the taxonomy of the group and provide an illustrated identification key. Our conclusions are supported by illustrations of all mentioned taxa and their types, and will be documented in FLOW (Bourgoin 2016).

\section{Material and methods}

The type specimens of all members of the clavatus group were examined. The male genitalia were dissected as follows: the pygofer was cut from the abdomen of the softened specimen with a needle blade, and then boiled for about one hour in a $10 \%$ solution of potassium hydroxide $(\mathrm{KOH})$ at about $100^{\circ} \mathrm{C}$. The pieces were examined in ethanol, and then placed in glycerine for preservation. Observations were done with a Leica MZ8 stereo microscope. Pictures were taken with a Canon EOS 300 D camera with a Sigma DG macro lens and optimized with Adobe Photoshop CS3 software. The inflation of the phallus was not done due to difficulty obtaining good and replicable results.

The measurements were taken as in Constant (2004) with the additions of Constant (2015) for the genus Pyrops and the following abbreviations are used: 
$\mathrm{BF}=$ maximum width of the frons

$\mathrm{BTg}=$ maximum width of the tegmen

$\mathrm{BPrH}=$ width of the cephalic process at half length

$\mathrm{LF} \quad=$ length of the frons in median line (excluding cephalic process)

$\mathrm{LPr}=$ length of the cephalic process

$\mathrm{LTg}=$ maximum length of the tegmen

$\mathrm{TL}=$ total length (apex of head to apex of tegmina)

(LF, LPr and TL measured to/from the anteocular carina at the base of the cephalic process)

Acronyms used for the collections:

BMNH = Natural History Museum, London, United Kingdom

EUM = Ehime University Museum, Matsuyama, Japan

HUIC = Hokkaido University Insect Collection, Sapporo, Japan

IZCAS = Zoological Museum, Institute of Zoology, Chinese Academy of Sciences, Beijing, P.R. China

MFNB = Museum für Naturkunde, Berlin, Germany

MHNL = Muséum d'Histoire naturelle de Lyon, France

NFIC $=$ National Forest Insect Collection, Forest Research Institute, Dehradun, India

NHRS = Naturhistoriska riksmuseet, Stockholm, Sweden

NMNS = National Museum of Natural Sciences, Taichung, Taiwan

NWAFU $=$ Entomological Museum of Northwest Agriculture and Forestry University, Yangling, China

OUMNH $=$ Oxford University Museum of Natural History, Oxford, United Kingdom

RBINS = Royal Belgian Institute of Natural Sciences, Brussels, Belgium

SDEI = Senckenberg Deutsche Entomologishe Institut, Müncheberg, Germany

UMUT = University Museum, University of Tokyo, Japan

VNMN = Vietnam National Museum of Nature, Hanoi, Vietnam

Original labels are quoted between square brackets.

\section{Results}

Class Hexapoda Blainville, 1816

Order Hemiptera Linnaeus, 1758

Suborder Auchenorrhyncha Duméril, 1806

Infraorder Fulgoromorpha Evans, 1946

Superfamily Fulgoroidea Latreille, 1807

Family Fulgoridae Latreille, 1807

Genus Pyrops Spinola, 1839

Pyrops Spinola, 1839: 231. Type species: Pyrops candelaria (Linnaeus, 1758) by subsequent designation by Duponchel (1840: 200).

Hotinus Amyot \& Serville, 1843: 490 (type species Pyrops candelaria (Linnaeus, 1758) by original designation) synonymized by Blanchard 1845: 425.

After comparison with the classification proposed by Lallemand (1963) and Nagai \& Porion (1996), the genus Pyrops is here removed from the subfamily Fulgorinae and not attributed to any of the currently defined subfamilies, following the conclusions of the DNA study by Urban \& Cryan (2009). The subfamily Fulgorinae is found in the New World, with the Neotropical genus Fulgora Linnaeus, 1767 as type. 


\section{Diagnostic characters}

The definition of the genus given by Constant (2015) is followed: head with cephalic process, sometimes very long, narrowing progressively beyond the eyes; apically it can be dilated or even spherical. Vertex about 4 times as broad as an eye. Before eyes, genae truncate, with a transverse carina which sometimes extends to vertex. Two longitudinal carinae on frons, a third median one starting on base of cephalic process. Fronto-clypeal suture usually slightly bisinuate; median carina on clypeus. Pronotum with median carina (sometimes obsolete) and a small but strongly impressed point on each side of it. Mesonotum with median and peridiscal carinae, sometimes obsolete. Tegmina at most 3 times as long as broad, with apical margin more or less rounded and with transverse veinlets on all surfaces. Clavus open and elongate, vein $\mathrm{A} 1+\mathrm{A} 2$ extending far towards apex. Legs slender.

\section{The clavatus species group}

This group was defined by Baker (1925: 348) with the following set of characters: (1) medium sized species; (2) cephalic process short, very stout, strongly clavate, black or olive green above and with red or ochraceous apex; (3) tegmina largely black.

It seems worth mentioning that Baker did not examine any specimen of $P$. atroalbus comb. nov. or P. watanabei.

Lallemand (1963: 88) restricted the definition to characters of the cephalic process only: "cephalic process rather short, much shorter than body, gradually narrowing, strongly dilated apically into a quite large ball" (translated from French).

Nagai \& Porion (1996) followed Lallemand's (1963) definition.

After examination of the types of all species placed in the group by previous authors, the combination of the following characters is given to define the group: (1) medium sized species; (2) cephalic process rather short, progressively narrowing towards apex and strongly swollen apically; (3) apical third of hind wings black or white.

The Philippine species P. polillensis is removed from the group based on the broad black area of the hind wing extending all along the sutural margin (see illustrations in Baker 1925), in contradiction with character (3), and not attributed to any of the currently defined species groups of Pyrops.

The three species included here in the group are distributed in a zoogeographically consistent zone extending from northern India eastwards to Taiwan through Bangladesh, Myanmar, northern Thailand, Laos and southern China, and southwards to central Vietnam.

\section{Identification key to the species of the Pyrops clavatus group}

1. Abdomen black ventrally (Fig. 1B); tegmina pale yellow-white on disc and with 3 black spots in costal area before nodal line (Fig. 1A); cephalic process yellow (Fig. 1D-F) (known from Laos, Thailand and Vietnam) Pyrops atroalbus (Distant, 1918) comb. nov.

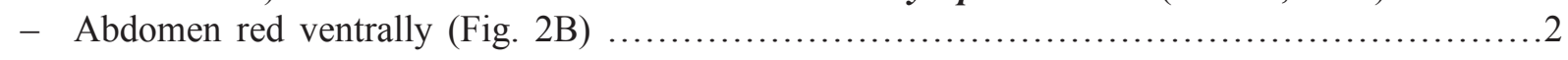

2. Tegmina largely black on disc (Fig. 2A), or in the pale forms (Fig. 3A, D), bluish white on disc and without black spots in costal area; cephalic process red-brown to black (Figs 2D-G, 3C, E) (known from N India, Bangladesh, N Myanmar, N Thailand, S China and N Vietnam) .........

- Tegmina mainly white on disc and with 3 black spots in costal area before nodal line (Fig. 4A, F); cephalic process yellow (Fig. 4D-E) (known from Taiwan) ...Pyrops watanabei (Matsumura, 1913) 
Pyrops atroalbus (Distant, 1918) comb. nov.

Figs 1, 5-6, 9A

Fulgora atroalba Distant, 1918: 199 (type in BMNH).

Laternaria atroalba - Metcalf 1947: 187 [transferred to Laternaria; catalogued].

Fulgora watanabei apicalis - Lallemand 1963: 90 [considered as a junior synonym of Fulgora watanabei atroalba (Distant, 1918) (erroneous)].

Fulgora watanabei atroalba - Lallemand 1963: 90 [transferred back to Fulgora and considered as a subspecies of $P$. watanabei (erroneous)].

Fulgora watanabei var. formosana - Lallemand 1963: 90 [considered as a junior synonym of Fulgora watanabei atroalba (Distant, 1918) (erroneous)].

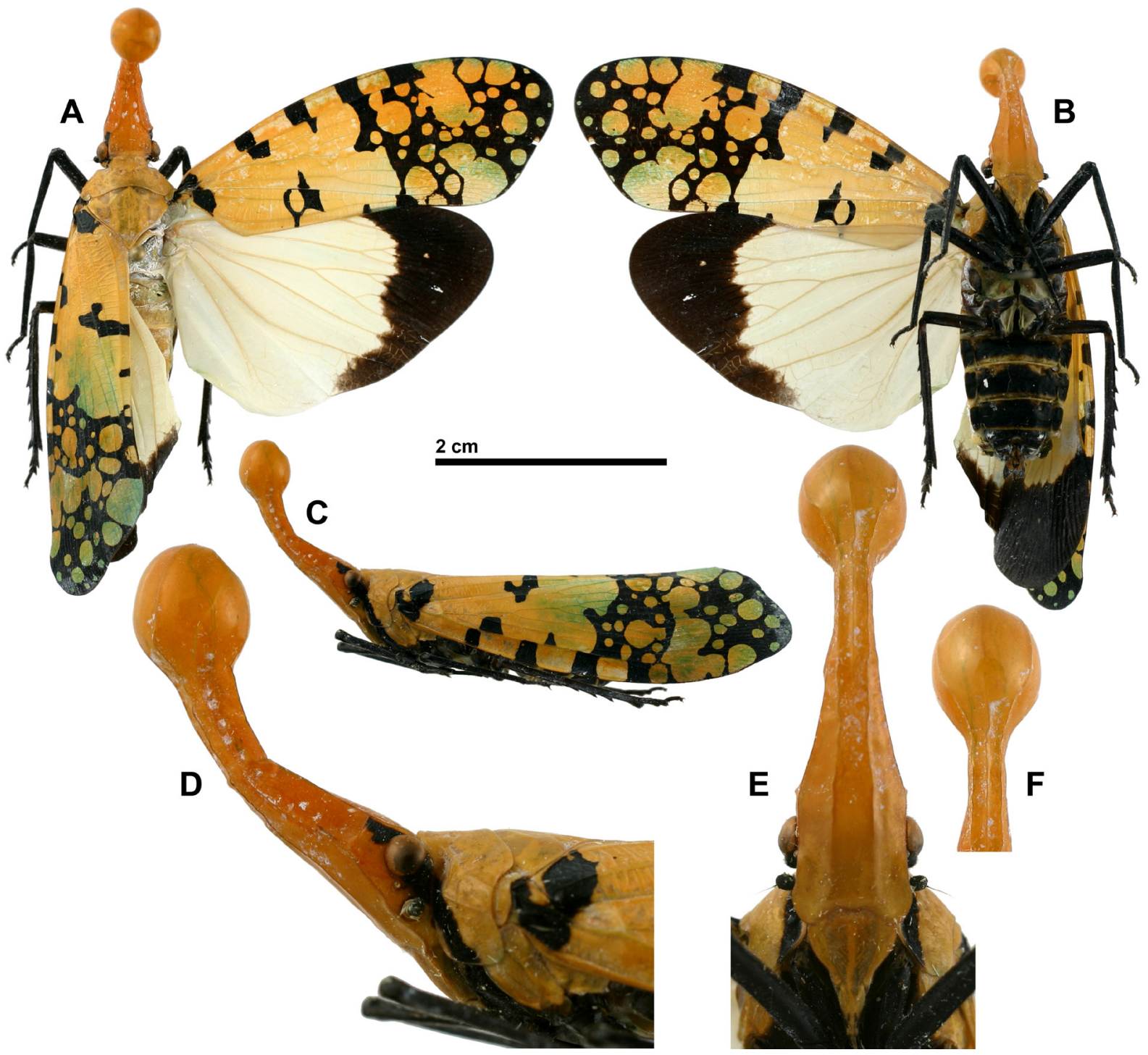

Fig. 1. Pyrops atroalbus (Distant, 1918) comb. nov., $q$, Vietnam, Quang Tri Prov., Da Krong Nature Reserve, 10 Jul. 2011 (VNMN). A. Habitus, dorsal view. B. Habitus, ventral view. C. Habitus, left lateral view. D. Head and thorax, left lateral view. E. Head, normal view of frons. F. Apex of cephalic process, frontal view. (D-F not to scale.) 


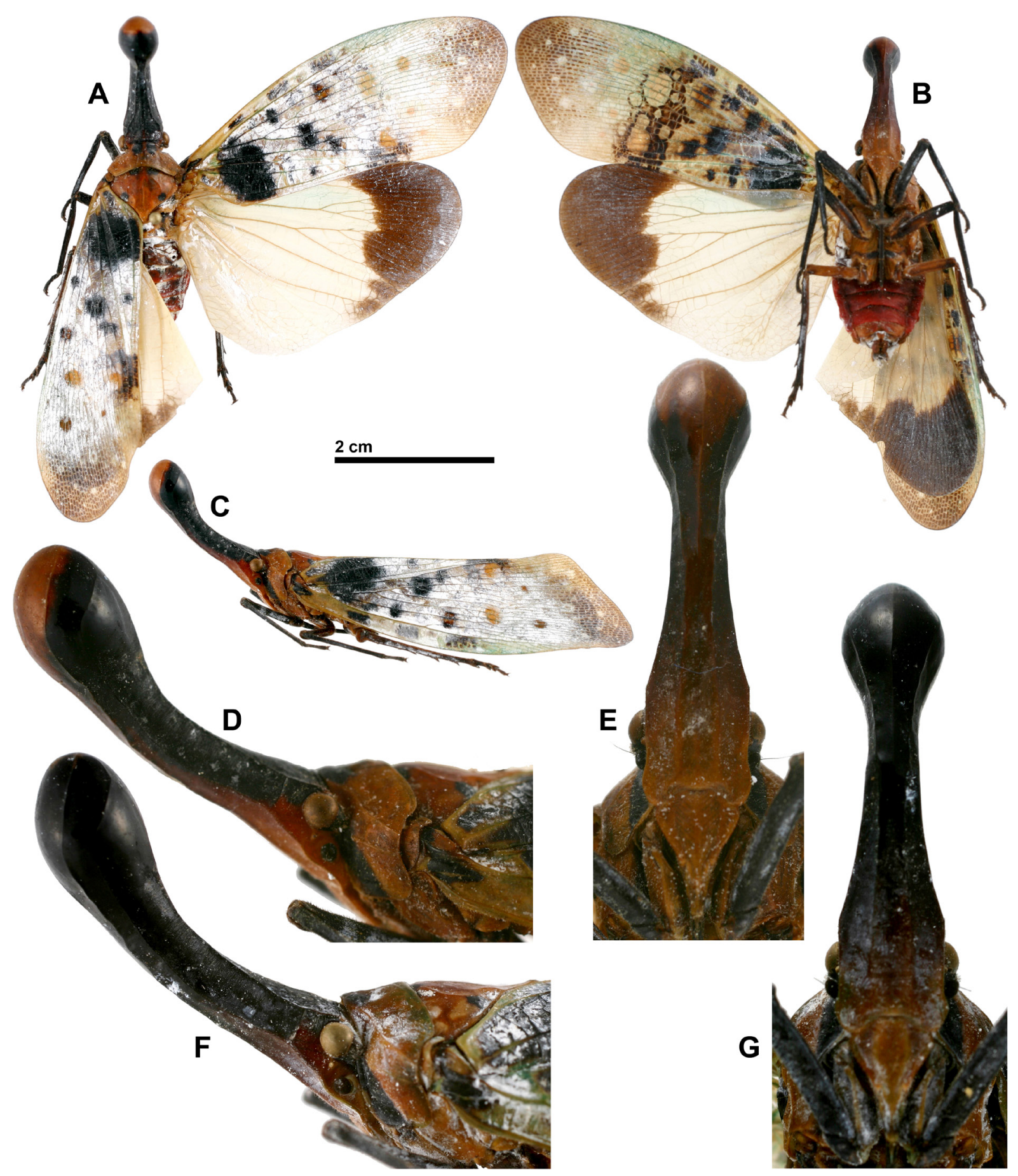

Fig. 2. Pyrops clavatus (Westwood, 1839), 우, Thailand, Chiang Mai, Dec. 2007 (RBINS). A-E. Dark specimen with cephalic process brown ventrally. A. Habitus, dorsal view. B. Habitus, ventral view. C. Habitus, left lateral view. D. Head and thorax, left lateral view. E. Head, normal view of frons. F-G. Dark specimen with black cephalic process. F. Head and thorax, left lateral view. G. Head, normal view of frons. (D-G not to scale.) 
Pyrops watanabei apicalis - Nagai \& Porion 1996: 26 [transferred to Pyrops but still considered as a junior synonym of Fulgora watanabei atroalba (erroneous)].

Pyrops watanabei atroalba - Nagai \& Porion 1996: 26, pl. 18, fig. 223 [transferred to Pyrops, but still considered as a subspecies of $P$. watanabei (erroneous), type illustrated]. - Liang 1998: 22 [considered as a subspecies of $P$. watanabei (erroneous)].

Pyrops watanabei formosana - Nagai \& Porion 1996: 26 [transferred to Pyrops but still considered as a junior synonym of Fulgora watanabei atroalba (erroneous)].

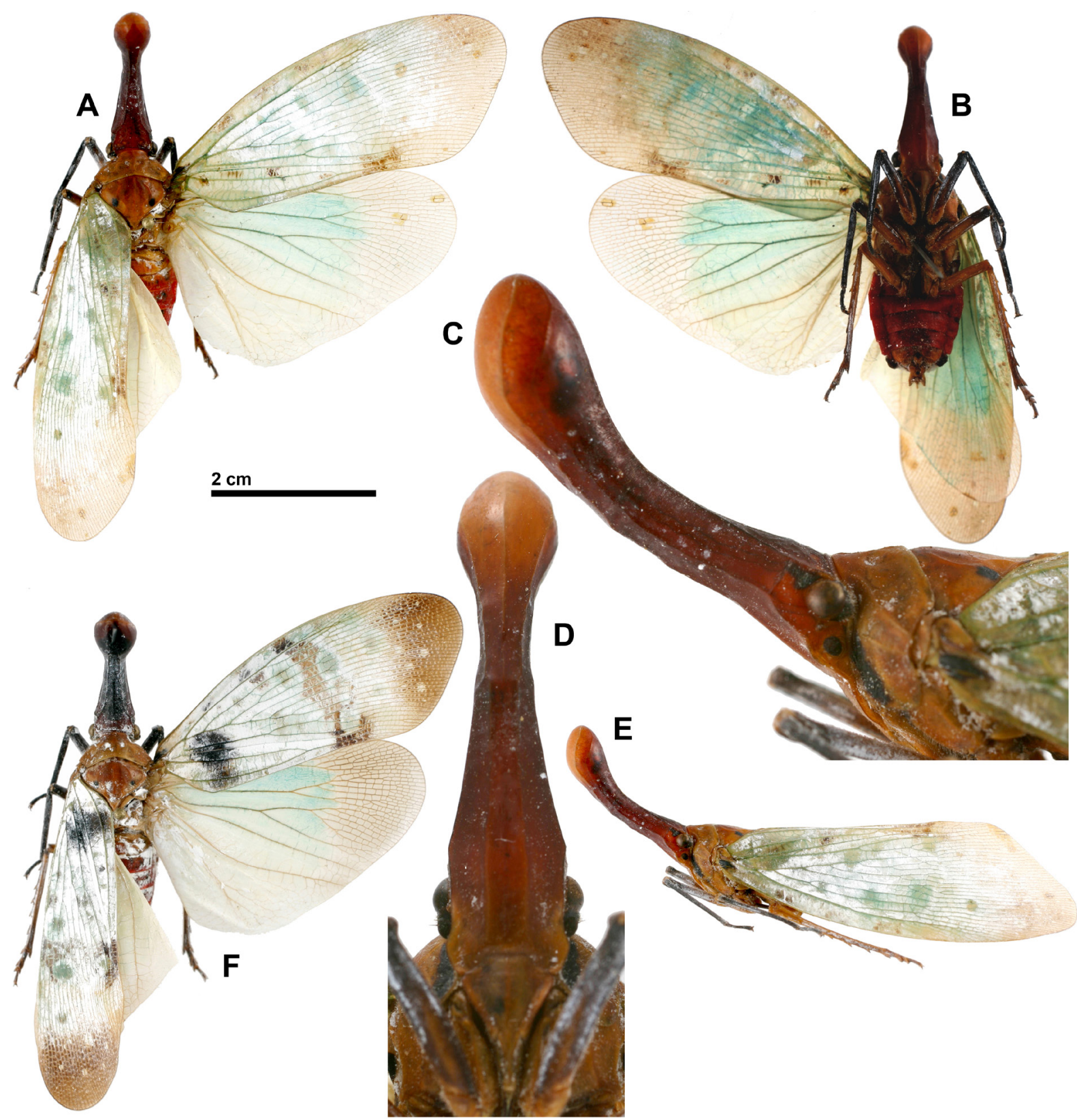

Fig. 3. Pyrops clavatus (Westwood, 1839), $\circ \propto$, Thailand, Chiang Mai, Dec. 2007 (RBINS). A-E. Pale specimen. A. Habitus, dorsal view. B. Habitus, ventral view. C. Head and thorax, left lateral view. D. Head, normal view of frons. E. Habitus, left lateral view. - F. Intermediate specimen with cephalic process black dorsally, habitus, dorsal view. (C-D not to scale.) 


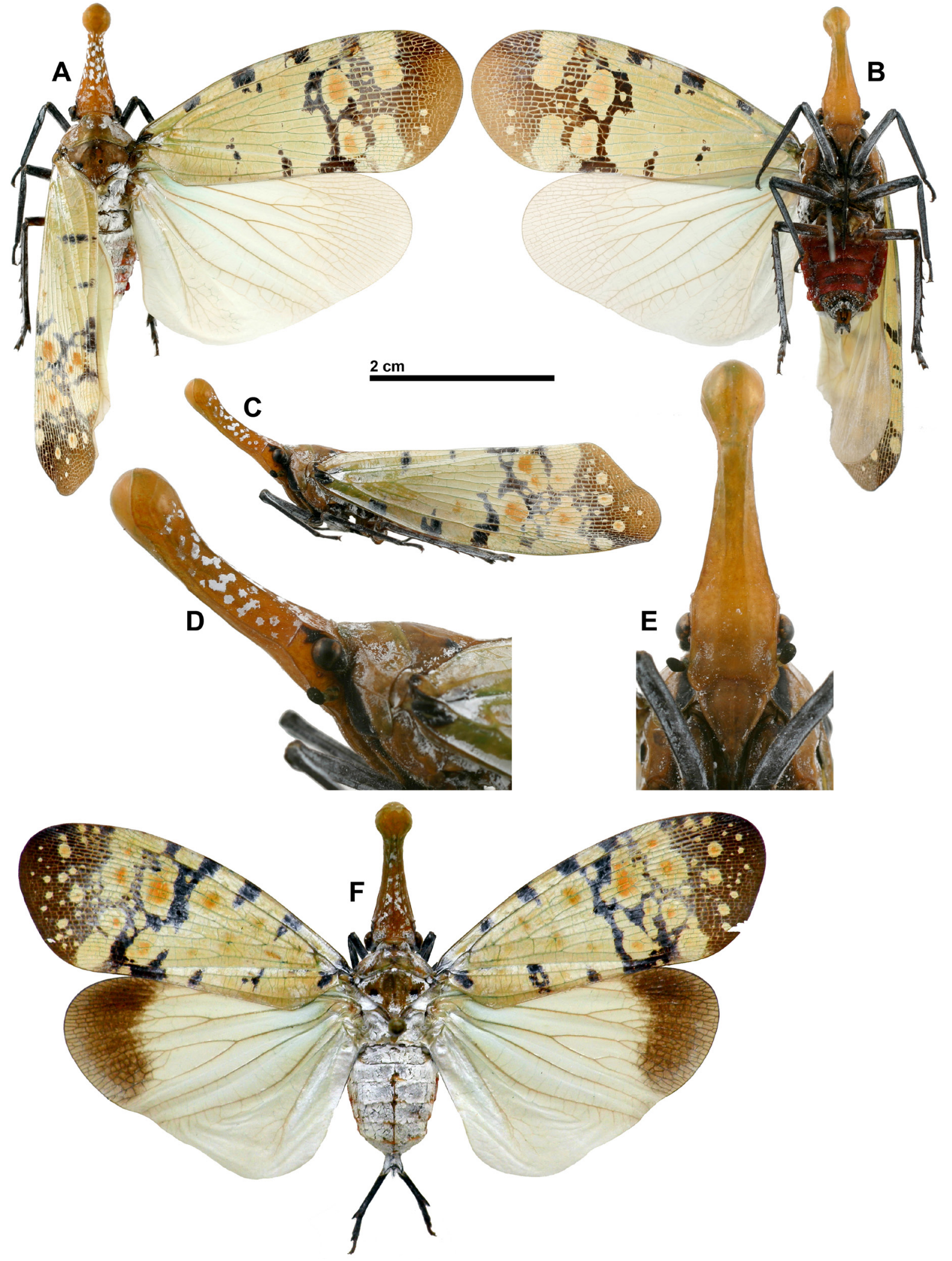

Fig. 4. Pyrops watanabei (Matsumura, 1913), 우. A-E. Pale specimen, Taiwan, Taipei, Tanshui, 14 Jun. 2002 (NMNS). A. Habitus, dorsal view. B. Habitus, ventral view. C. Habitus, left lateral view. D. Head and thorax, left lateral view. E. Head, normal view of frons. - F. Dark specimen, Taiwan, Tao Yuan, 10 Jul. 2007 (MHNL, photograph by C. Audibert), habitus, dorsal view. (D-E not to scale.) 
Non Fulgora watanabei apicalis Kato, 1928: 221, pl. 9 fig. 1.

Non Fulgora watanabei var. formosana Metcalf, 1947: 208.

\section{Note}

Liang (1998) erroneously stated that the name "Pyrops watanabei atroalbus (Distant, 1918)" was a new combination he proposed while the combination had already been proposed by Nagai and Porion (1996).

\section{Diagnosis}

The species is immediately recognized by the following combination of characters:

(1) Cephalic process yellow and strongly inflated apically (Fig. 1D-F).

(2) Abdomen black ventrally (Fig. 1B).

(3) Tegmina strongly contrasted: pale yellow-white with black markings, including 3 black spots in costal area before nodal line (Fig. 1A).

\section{Etymology}

From Latin ater (adj.) 'black' and albus (adj.): 'white'; the species epithet refers to the black and white colouration of the species.

\section{Type material}

Holotype (Fig. 5)

VIETNAM: ổ [Indo-China, Tonkin, R.V. de Salvaza. 1917-98] [1918-1] [Fulgora atroalba Dist. Type] [Type] (BMNH).

\section{Additional material}

VIETNAM: 1 đ̊, 1 q, Da Krong Nature Reserve, Quang Tri Province, 10 Jul. 2011, 16 $37^{\prime}$ N, $106^{\circ} 47^{\prime}$ E, day collecting, Pham \& Hoang ( $\partial^{\lambda}$ in RBINS, $q$ in VNMN); 1 + , Bach Ma National Park, 29 Sep. 2014, $16^{\circ} 12^{\prime} \mathrm{N}, 107^{\circ} 52^{\prime} \mathrm{E}$, Tuan (VNMN).

\section{Material examined from photograph}

THAILAND: 1 ex. (Fig. 9A), Chiang Mai Prov., Maerim District, 1854'50" N, 98 56'42" E, 14 Mar. 2016, Panaka Jirasuttayaporn.

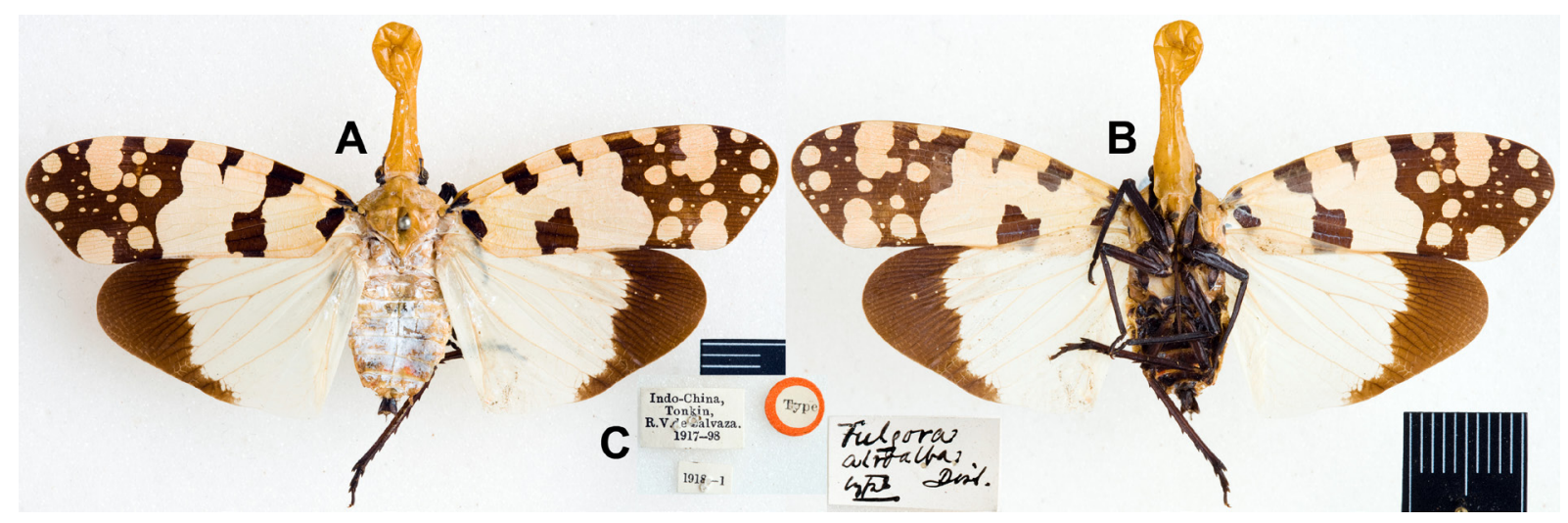

Fig. 5. Pyrops atroalbus (Distant, 1918) comb. nov., holotype $\widehat{\jmath}$ (BMNH, photographs by D. Croucher). A. Habitus, dorsal view. B. Habitus, ventral view. C. Labels. 


\section{Measurements and ratios}

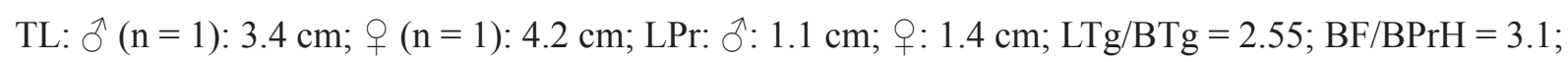
$\mathrm{LPr} / \mathrm{LF}=2.95 ; \mathrm{LPr} / \mathrm{BPrH}=8.8$.

\section{Male genitalia}

Pygofer higher than long, with posterior margin regularly rounded dorsally in lateral view (Fig. 6A). Anal tube slightly elongate, 1.1 times as long as broad in dorsal view, broader at $4 / 5$ of total length (Fig. 6C); lateral margins very slightly sinuate and apical margin strongly concave in dorsal view (Fig. 6C). Gonostyli (Fig. 6A) elongate, twice as long as high in lateral view; dorsal margin regularly rounded and posterior margin slightly projecting posteriorly in middle in lateral view (Fig. 6A).

\section{Remarks}

There is a discrepancy between the location given on the label of the specimen ("Tonkin") and the one given in the original description (Distant 1918): "Indochina, Xieng Klouang (R. Vitalis de Salvaza)". The latter location is situated in Laos, not far from the places where we have collected specimens in Central Vietnam. Despite our intensive collecting effort in northern Vietnam, we have never found the species in that region. Hence, it seems that the location given by Distant (1918) is more likely to be the correct one.

Nagai \& Porion (1996: fig. 223) erroneously gave “central Taiwan” as the type locality.

\section{Distribution}

The species is known from one location in Laos, one in Northern Thailand, and two in Central Vietnam.

Pyrops clavatus (Westwood, 1839)

Figs $2-3,7,9 \mathrm{~B}-\mathrm{G}, 10-15$

Fulgora clavata Westwood, 1839: 139, pl. 12, fig. 1 (types in OUMNH) [described, illustrated, compared with P. pyrorhynchus (Donovan, 1800), the latter mentioned as the junior synonym Fulgora pyrorhina Westwood, 1839)].

Hotinus ponderosus Stål, 1854: 244 (type in NHRS) [described and mentioned as close to P. clavatus; synonymized by Distant (1906)].

Fulgora woodii Ollenbach, 1929: 279, pl. 1, fig. 13 (types in NFIC) [described, illustrated and mentioned as very near to Pyrops clavatus; synonymized by Lallemand (1963)].

Fulgora nigripennis Chou \& Wang in Chou et al., 1985: 33, fig. 4 (type in NWAFU) [described in Chinese, illustrated, compared to P. clavatus], 37 (briefly described in Esperanto, host plant) syn. nov.

Fulgora clavata mizunumai Satô \& Nagai, 1994: 312, figs 3, 12 (type in EUM) [described, illustrated, compared to $P$. clavatus] syn. nov.

Pyrops clavata - Burmeister 1845: 4 [transferred to Pyrops]. — Schaum 1850: 64 [listed] — Kirby 1885: 211 [mentioned from India and briefly described]; 1892: 211 [idem]. — Nagai \& Porion 1996: 26 [catalogued; distribution]; 31 [very close to Fulgora nigripennis Chou \& Wang, 1985], pl. 18, figs $227-228$ [illustrated].

Hotinus clavatus - Adams 1847: 204 [compared with P. sultanus (Adams \& White, 1847)]. — Walker 1851: 267 [list of specimens in BMNH]; 1858: 41 [clavatus as the type and single member of a group within Hotinus]. — Stål 1854: 244 [close to Hotinus ponderosus Stål, 1854]. — Costa 1864: 82 [listed from Assam].

Fulgora (Hotina [sic!]) clavata - Westwood 1848: 7, pl. 3, fig. 1 [described, illustrated]. 

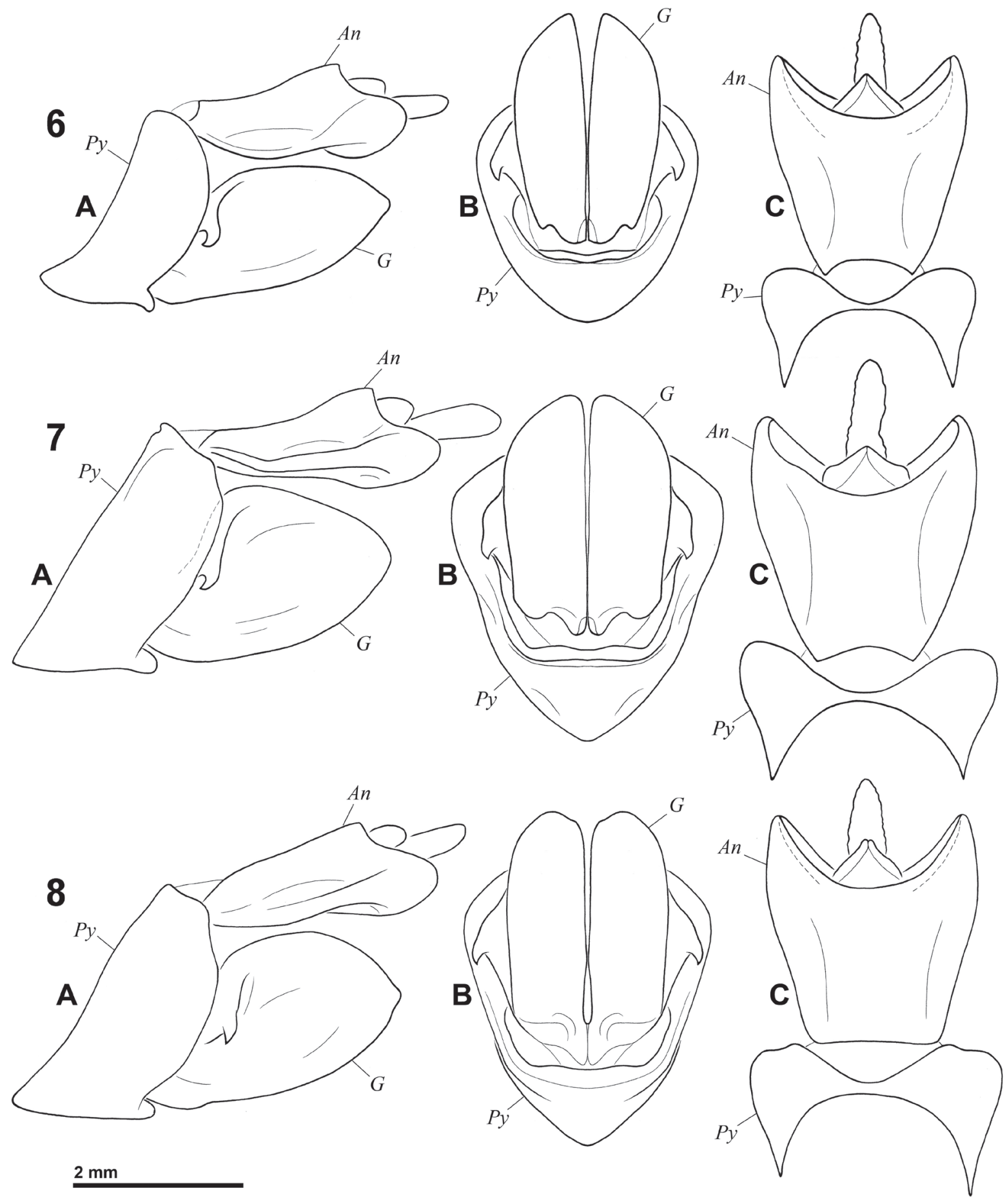

Figs 6-8. Pyrops clavatus group, male genitalia. 6. Pyrops atroalbus (Distant, 1918) comb. nov. 7. P. clavatus (Westwood, 1839). - 8. P. watanabei (Matsumura, 1913). A. Pygofer, anal tube and gonostylus, left lateral view. B. Pygofer and gonostyli, posteroventral view. C. Anal tube and pygofer, dorsal view. Abbreviations: $A n=$ anal tube; $G=$ gonostylus; $P y=$ pygofer. 

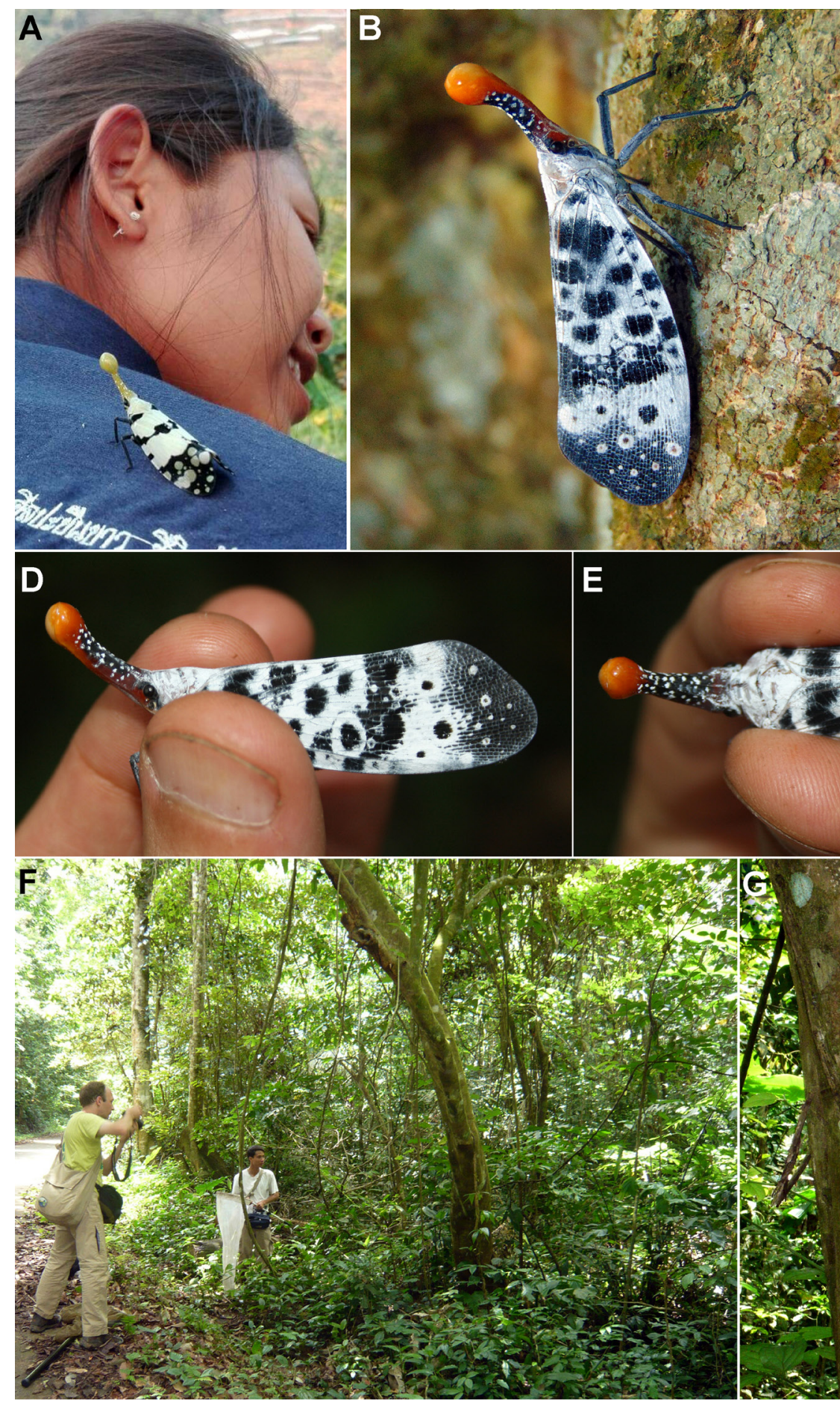

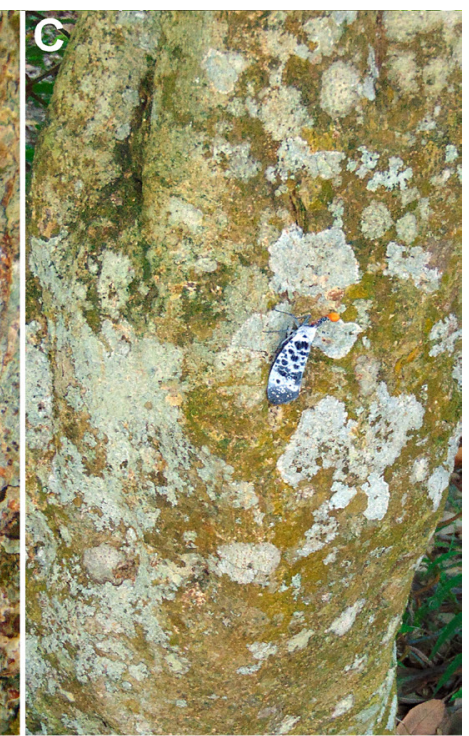

E

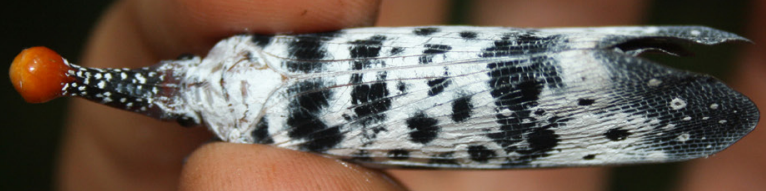

Fig. 9. Specimens of Pyrops clavatus group in nature. A. P. atroalbus (Distant, 1918) comb. nov. in Maerim District, N Thailand, 14 Mar. 2016 (photograph by P. Jirasuttayaporn). B-C. P. clavatus (Westwood, 1839) on a trunk of Dimocarpus longan (Sapindaceae) at Me Linh Biological Station, N Vietnam, 12 Jul. 2015 (photographs by J. Constant). D-E. P. clavatus (Westwood, 1839) in Cuc Phuong National Park, N Vietnam, 21 Jul. 2011 (photographs by J. Constant). F. The authors in the habitat of P. clavatus (Westwood, 1839) in Cuc Phuong National Park, N Vietnam, 21 Jul. 2011 (photograph by J. Bresseel). G. P. clavatus (Westwood, 1839) together with P. spinolae (Westwood, 1842), specimens in Cuc Phuong National Park, N Vietnam, 21 Jul. 2011 (photograph by J. Constant). 
Hotinus ponderosus - Walker 1858: 315 [listed from Hindustan]. — Distant 1906: 191 [junior synonym of $P$. clavatus (Westwood, 1839)].

Fulgora clavata - Butler 1874: 98 [placed in a section of Fulgora with white hind wings; list of specimens in BMNH; mention of "ludicrous" cephalic process; probable senior synonym of "Fulgora ponderosa"]. - Gadeau de Kerville 1881: 43 [listed as light-producing insect (erroneous)]. Atkinson 1885: 130 [catalogued; described; distribution; intraspecific variation]. — Schmidt 1905: 354 [catalogued]. - Distant 1906: 191; fig. 83 [keyed; described; habitus, side of head and frons illustrated; senior synonym of Hotinus ponderosus Stål, 1854]. — Schumacher 1915: 129 [compared with Fulgora chimara Schumacher, 1915]. — Distant 1918: 198 [listed from "Indochina"], 200 [compared with P. atroalbus (Distant, 1918)]. - Paiva 1919: 373 [mentioned from Garo Hills, N India; notes on biology]. - Baker 1925: 348 [type of the clavata group in Fulgora], 361 [key to the species of the clavata group; described], pl. 4, fig. 1 [lateral aspect of habitus illustrated]. Ollenbach 1929: 280 [compared with Fulgora woodi Ollenbach, 1929]. — Lallemand 1963: 71 [type of $5^{\text {th }}$ group of Fulgora], 88 [keyed; described; catalogued; senior synonym of Hotinus ponderosus Stål, 1854 and Fulgora woodi Ollenbach, 1929]; pl. 10, figs 4-7 [lateral view of head and male genitalia of type illustrated]. - Satô \& Nagai 1994: 312 [compared with Fulgora clavata mizunumai Satô \& Nagai, 1994].

Fulgora ponderosa - Butler 1874: 98 [probable junior synonym of $P$. clavatus]. — Gadeau de Kerville 1881: 43 [listed as light-producing insect (erroneous)]. - Atkinson 1885: 131 [catalogued; described; distribution; probable variety of $P$. clavatus].

Fulgora ponderosus - Matsumura 1913: 54 [close to P. watanabei (Matsumura, 1913)].

Laternaria clavata - Metcalf 1947: 193 [catalogued; distribution]. — Allnatt 2013: 45, fig. 1 [illustrated from Assam].

Laternaria clavata var. ponderosa - Metcalf 1947: 193 [catalogued; distribution; considered as a variety of clavatus (erroneous)].

Laternaria woodi - Metcalf 1947: 208 [catalogued].

Pyrops clavata mizunumai - Nagai \& Porion 1996: 26 [catalogued]; pl. 18, figs 222, 224, 226 [illustrated].

Pyrops clavatus - Liang 1998: 42 [catalogued; new combination (erroneous)].

Pyrops clavatus mizunumai - Liang 1998: 42 [catalogued; new combination (erroneous)].

\section{Diagnosis}

The species is immediately recognized by the following combination of characters:

(1) Cephalic process red-brown to black, often black with apex red-brown, and strongly inflated apically (Figs 2D-G, 3C, E).

(2) Abdomen red ventrally (Figs 2B, 3B).

(3) Tegmina largely black on disc in the dark forms (Fig. $1 \mathrm{~A}-\mathrm{B}$ ); in the pale forms, tegmina bluish white on disc without black spots in costal area (Fig. 3A-B, D).

\section{Etymology}

clavatus (adj., Latin): clavate. The name refers to the shape of the cephalic process.

\section{Material examined}

\section{Type material}

BANGLADESH: Lectotype, of of Fulgora clavata Westwood, 1839, here designated to provide a reference standard for the species (examined from photographs, Fig. 10) [Silhet] [Fulgora clavata Westw. Trans. Lin. Soc. 18. P. 139 Pl 12 Fig 5.] [Type] [Type Hem : 596 1/2 Fulgora clavata Westwood, Hope Dept. Oxford] (OUMNH). 
BANGLADESH: Paralectotype, + of Fulgora clavata Westwood, 1839 (examined from photographs, Fig. 11) [Silhet] [Fulgora clavata Westw. Monogr. M. Hope, Sylhet] [W] [Type] [Type Hem : 596 2/2 Fulgora clavata Westwood, Hope Dept. Oxford] (OUMNH).

INDIA: Holotype, + of Hotinus ponderosus Stål, 1854 (Fig. 12) [Ind or] [Saund] [ponderosus Stål] [NHRS-HEMI000000198] (NHRS).
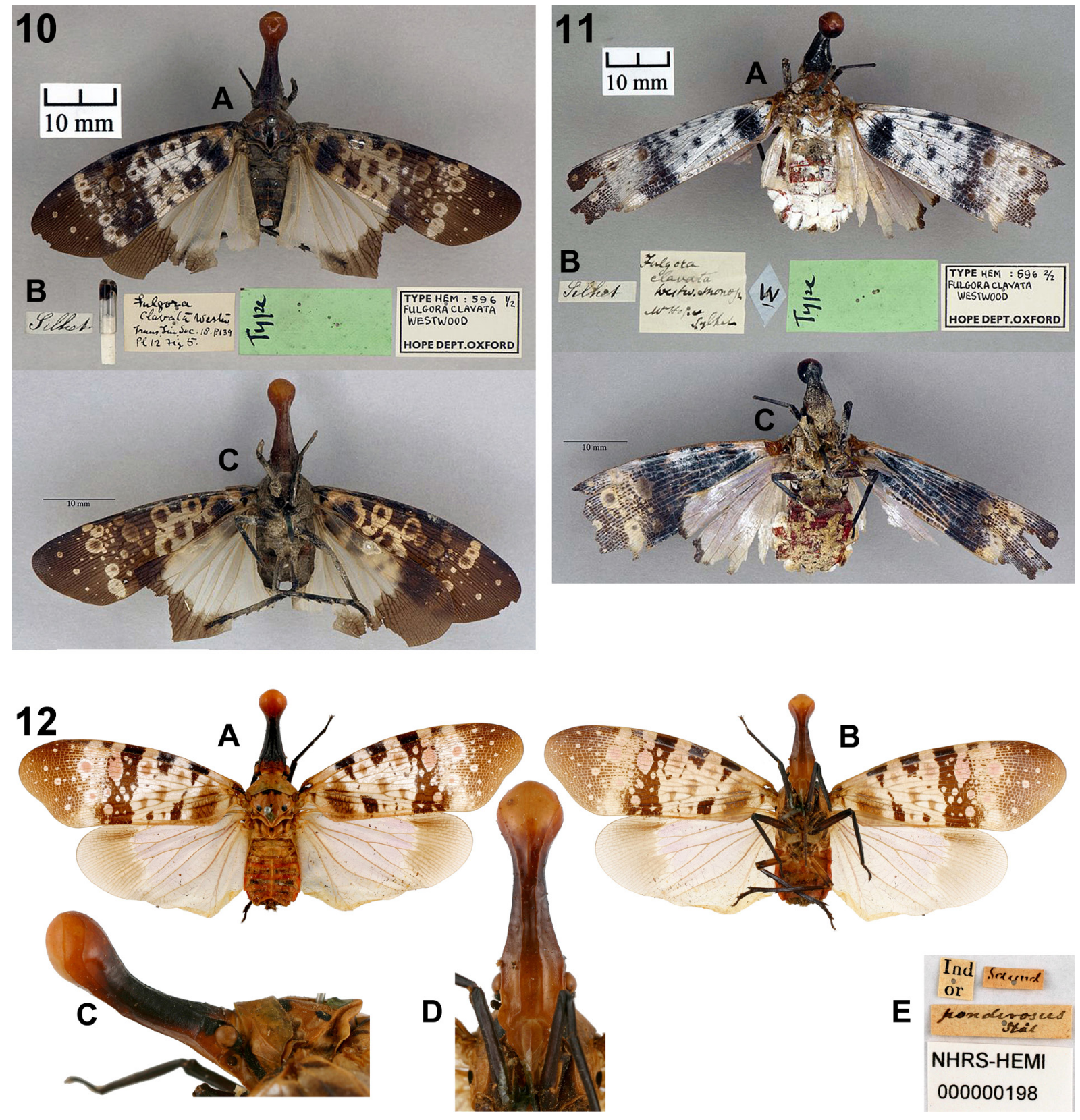

Figs 10-12. Pyrops clavatus (Westwood, 1839) and synonymised species, type specimens. 10. Fulgora clavata Westwood, 1839, lectotype, ô (OUMNH, photographs by A. Spooner). A. Habitus, dorsal view. B. Labels and genitalia tube. C. Habitus, ventral view. - 11. F. clavata Westwood, 1839, paralectotype, $q$ (OUMNH, photographs by A. Spooner). A. Habitus, dorsal view. B. Labels. C. Habitus, ventral view. 12. Hotinus ponderosus Stål, 1854, holotype, + (NHRS, photographs by J. Constant). A. Habitus, dorsal view. B. Habitus, ventral view. C. Head and thorax, left lateral view. D. Head, normal view of frons. E. Labels. Wingspan: $88 \mathrm{~mm}$. 
MYANMAR: Syntype, ô of Fulgora woodii Ollenbach, 1929 (examined from photographs, Fig. 13) [Paga-yo, Tavoy, 27.I.20, O.C. Ollenbach] [Type] [Fulgora woodii (Ollen) $\partial^{\lambda}$ n sp., O.C. Ollenbach det.] (NFRI).

CHINA: Holotype, $\widehat{\jmath}$ of Fulgora nigripennis Chou \& Wang, 1985 (examined from photographs, Fig. 14) [Fulgora nigripennis Chou, Wang \& Huang "identified by Io Chou, August 1982"] ["Host plant: coffee"] [HOLOTYPE] (NWAFU). - Parts in italics between " " were translated from Chinese by D. Qin. The specimen was collected in Ruyuan, Guangdong Province in May 1975 by Lizhong Hua (D. Qin pers. comm., Jun. 2016).

THAILAND: Holotype, Ô of Fulgora clavata mizunumai Satô \& Nagai, 1994 (examined from photographs, Fig. 15) [Doi Pui, Chiang Mai (N Thailand) May 1987] [Holotype Fulgora clavata mizunumai] (EUM).

\section{Additional material}

INDIA: 1 , Darjeeling (Himalaya), 1869, Higgins (RBINS); 1 q, Kurseong, no date, R.P. Wery (RBINS).

THAILAND: $5 \hat{\jmath}, 15$ 우, Chiang Mai, Dec. 2007, local collectors (RBINS).

VIETNAM: 1 q, Ha Giang, Jul. 2009, local collectors (RBINS); 2 우, Cuc Phuong National Park, $20^{\circ} 19^{\prime} 00^{\prime \prime} \mathrm{N}, 105^{\circ} 36^{\prime} 30^{\prime \prime} \mathrm{E}, 19-23 \mathrm{Jul}$. 2011, day collecting, on tree trunk, leg. J. Constant and J. Bresseel (RBINS); 2 우, Cuc Phuong N.P., 25 May 2005, leg. H.T. Pham (VNMN); 3 $\sigma^{\lambda}, 3$ q $q$, Lao Cai Prov., Sa Pa Mt, 1800 m, Oct. 2014, leg. Than Le Luong (RBINS); 1 +, Vinh Phuc Prov., Me Linh Station, 12

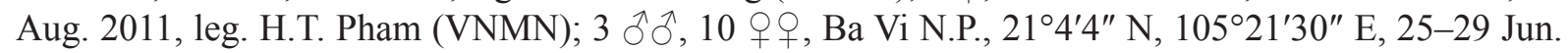

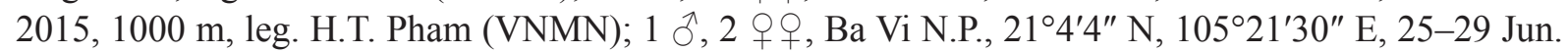
2015, 600 m, leg. J. Constant and J. Bresseel (RBINS); 1 , Nghe An Prov., Pu Mat N.P., $18^{\circ} 59^{\prime}$ N, 104 $40^{\prime}$ E, Jul. 2014, local collector (RBINS); 1 q, Tuyên Quang Prov., Cham Chu Nature Reserve, $22^{\circ} 12^{\prime} \mathrm{N}, 105^{\circ} 6^{\prime} \mathrm{E}, 8^{-1}-12$ Jul. 2015, leg. J. Constant and J. Bresseel (RBINS); 2 $\hat{\partial}$, same data, leg. H.T. Pham (VNMN); 1 , , Quang Binh Prov., Phong Nha-Ke Bang N.P., U Bo, $17^{\circ} 32^{\prime} 14^{\prime \prime}$ N, $106^{\circ} 9^{\prime} 4^{\prime \prime}$ E,

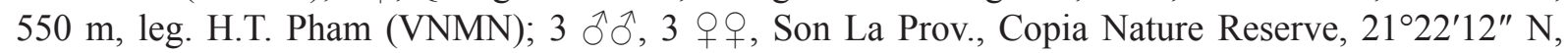
$103^{\circ} 30^{\prime} 42^{\prime \prime}$ E, 20-23 Jul. 2016, J. Constant and J. Bresseel (RBINS).

\section{Material examined from photographs}

INDIA: 1 ex., Assam, Mangaldai, 13 Aug. 2014, Mirza Galib (Facebook group: InsectIndia); 1 ex., Manipur, Loktak Lake, 9 Oct. 2014, Sougrakpam Neli (Facebook group: InsectIndia); 1 ex., Nagaland, Aug. 2012, Tarun Karmakar (Facebook group: InsectIndia); 1 ex., Upper Assam, Dibrugarh, Rungagora, no date, H. Stevens (Alnatt 2013: fig. 1).

VIETNAM: 1 ex. (Fig. 9B-C), Me Linh Biological Station, 12 Jul. 2015, on a trunk of Dimocarpus longan (Sapindaceae), J. Constant.

\section{Additional data from literature}

INDIA: Garo Hills above Tura, $3000 \mathrm{ft}$ (Paiva 1919).

MYANMAR: Karen Hills (Ollenbach 1929 - location of the second syntype of Fulgora woodi).

\section{Measurements and ratios}

TL: $\widehat{\partial}(\mathrm{n}=5): 3.9 \mathrm{~cm}(3.7-4.0)$; LPr: $1.2 \mathrm{~cm}(1.1-1.3)$; TL: $ᄋ(\mathrm{n}=5): 5.1 \mathrm{~cm}(4.5-5.5)$; LPr: $1.35 \mathrm{~cm}$ $(1.3-1.5) ; \mathrm{LTg} / \mathrm{BTg}=2.47 ; \mathrm{BF} / \mathrm{BPrH}=2.05 ; \mathrm{LPr} / \mathrm{LF}=3.19 ; \mathrm{LPr} / \mathrm{BPrH}=6.13$. 


\section{Male genitalia}

Pygofer higher than long, with posterior margin angularly bisinuate dorsally in lateral view (Fig. 7A). Anal tube slightly elongate, 1.1 times as long as broad in dorsal view, broader at $4 / 5$ of total length (Fig. 7C); lateral margins very slightly sinuate and apical margin strongly concave in dorsal view (Fig. 7C). Gonostyli (Fig. 7A) elongate, 1.5 times as long as broad in lateral view; dorsal margin strongly rounded above lateral tooth and posterior margin rounded in lateral view (Fig. 7A).
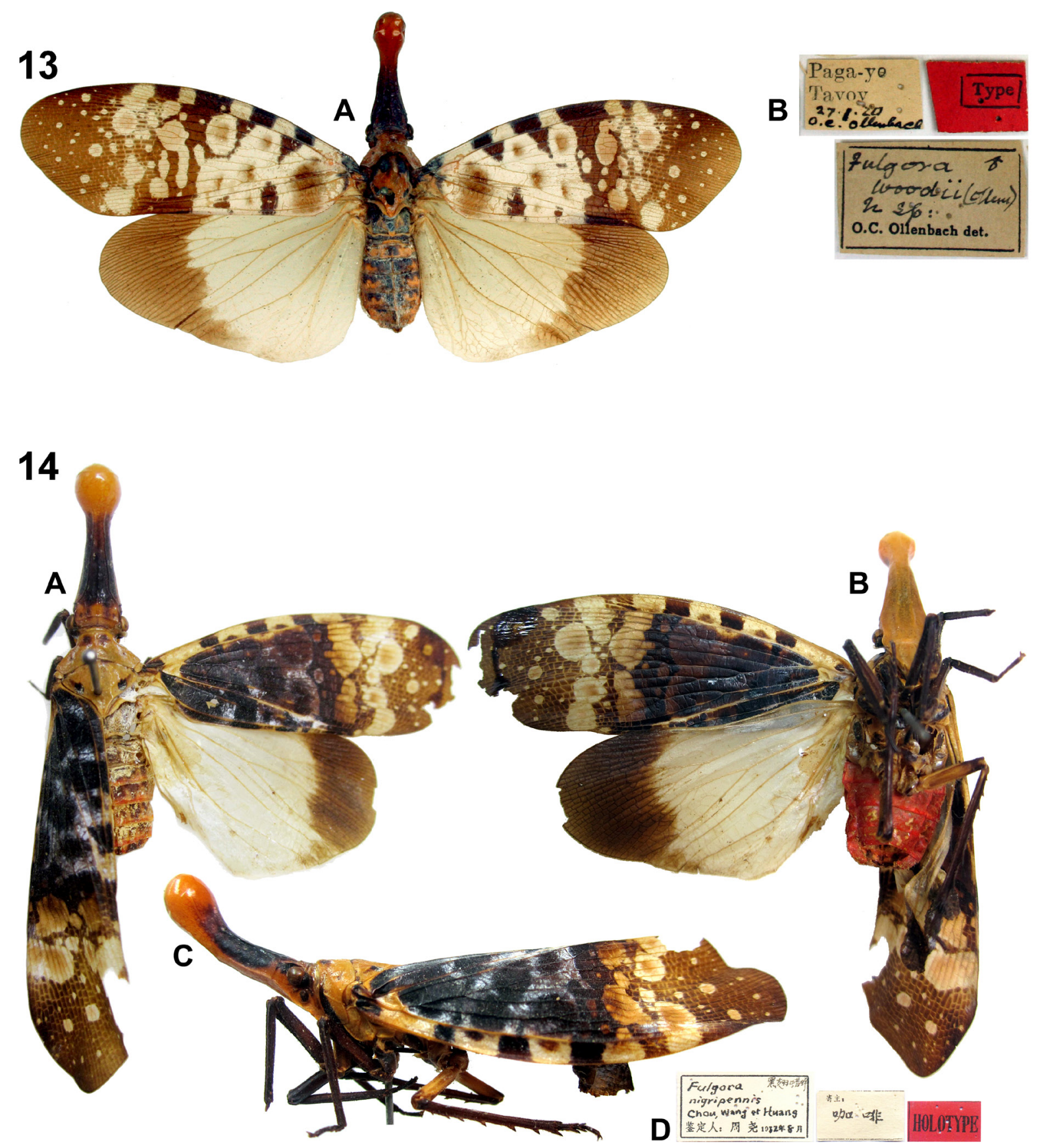

Figs 13-14. Pyrops clavatus (Westwood, 1839), type specimens of the synonymised species. 13. Fulgora woodi Ollenbach, 1929, syntype, ổ (NFIC, photographs by S. Singh). A. Habitus, dorsal view. B. Labels. Wingspan: $80 \mathrm{~mm}$ - 14. Fulgora nigripennis Chou \& Wang, 1985, holotype, ふ઼ (NWAFU, photographs by D. Qin). A. Habitus, dorsal view. B. Habitus, ventral view. C. Habitus, lateral view. D. Labels. Total length: $37 \mathrm{~mm}$. 


\section{Remarks}

After examination of the photographs of the type specimens of Fulgora nigripennis Chou \& Wang, 1985 and Fulgora woodii Ollenbach, 1929, it was not possible to find any difference between those taxa and the types of $P$. clavatus and the recorded intraspecific variations of the species. Hence, the first is proposed as a junior synonym of Pyrops clavatus and the synonymy of the second under P. clavatus, as proposed by Lallemand (1963) and followed by Nagai \& Porion (1996), is confirmed.

Ollenbach (1929) stated that the types of the species described in his paper would later be sent to the British Museum (currently BMNH) but he apparently never did so as none of the types of those species can be found in the BMNH collections (M. Webb pers. comm., 21 May 2013).

The examination of numerous specimens of P. clavatus, including large series from Chiang Mai (Figs 2-3) and northern Vietnam, proved that the species shows important intraspecific colour variation of the cephalic process and wings: the tegmina vary from nearly completely black to nearly completely bluish white, the hind wings from white with black apex to completely white, usually tinged with blue or violet basally. The "subspecies" mizunumai described by Satô \& Nagai (1994) only represents the paler extreme of the species and cannot be considered as a subspecies, as it occurs sympatrically with

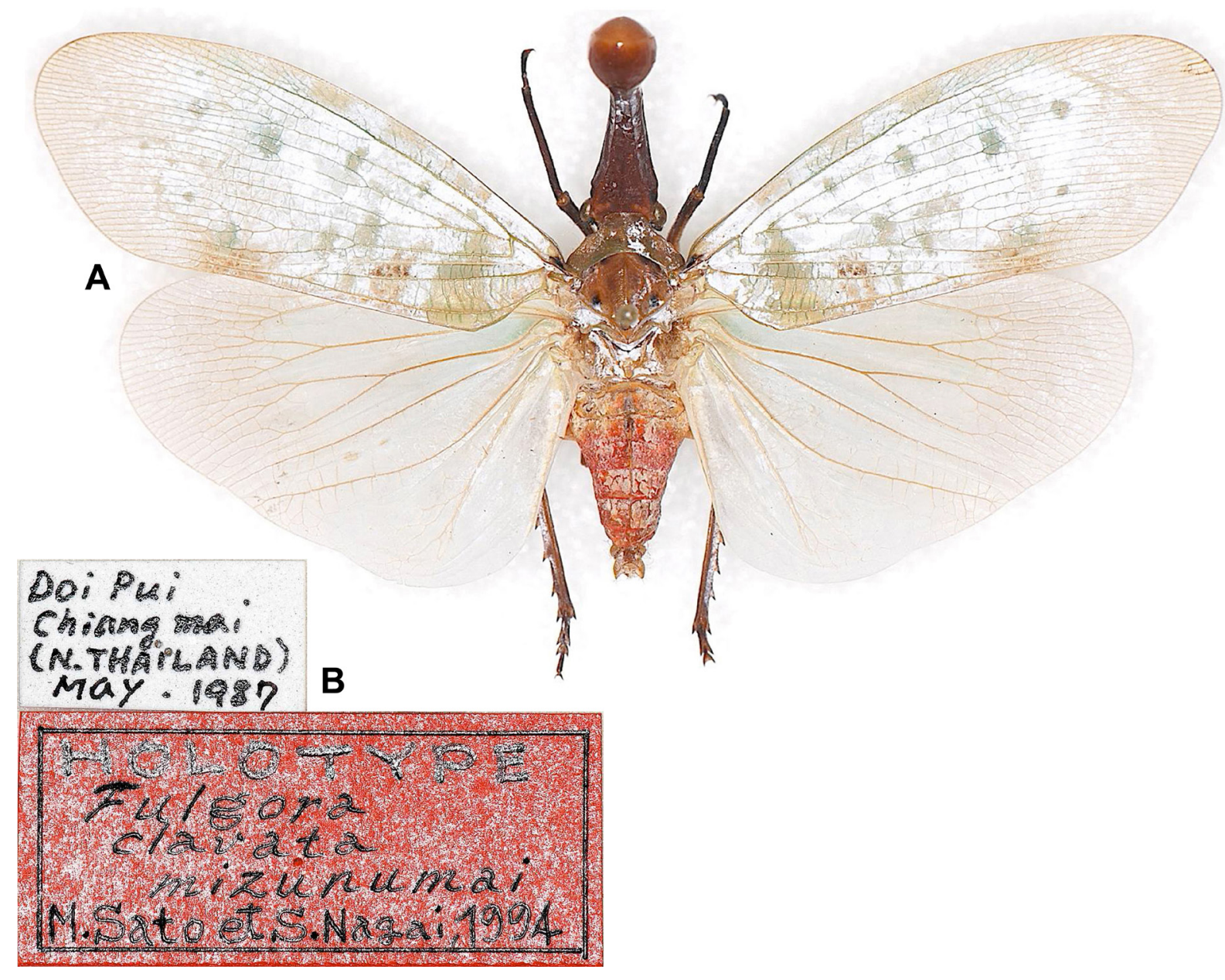

Fig. 15. Pyrops clavatus (Westwood, 1839), holotype, $\hat{o}$ of the junior synonym Fulgora clavata mizunumai Sato \& Nagai, 1994 (EUM, photographs by H. Yoshitomi). A. Habitus, dorsal view. B. Labels. Wingspan: $75.4 \mathrm{~mm}$. 
the intermediate and darker forms. It is therefore synonymized under P. clavatus. Specimens showing basally blue-tinged and violet-tinged hind wings were found in the same population, on the same tree in Copia, North Vietnam. The variation is not linked to the sex of the specimens as both males and females showed the two variations.

\section{Biology}

Paiva (1919) stated that the species was "not uncommon at $3000 \mathrm{ft}$. Several specimens sometimes found on a single tree to which they return after disturbance". Our observations confirm this statement which is valid for most species of Pyrops we have observed so far. We have found P. clavatus feeding on several unidentified species of tree in Ba Vi National Park (north Vietnam); in Cuc Phuong National Park (north Vietnam), some specimens of P. clavatus were found on a big tree together with numerous Pyrops spinolae (Westwood, 1842), while other trees of the same species and others around did not host any Pyrops specimens (Fig. 9F-G); at Me Linh Biodiversity Station (north Vietnam), P. clavatus was observed on a big Longan tree trunk (Dimocarpus longan Lour., Sapindaceae) together with $P$. candelaria (Linnaeus, 1758), P. lathburii (Kirby, 1818) and P. viridirostris (Westwood, 1848). In North Vietnam we found the species at altitudes ranging from 150 to $1200 \mathrm{~m}$.

The species was also collected on coffee (Coffea sp., Rubiaceae) in southern China.

\section{Distribution}

Known from N India, Myanmar, N Thailand, S China and N Vietnam.

Very probably also present in Laos and maybe in Cambodia (see also Constant et al. 2016 for discussion on Fulgoridae from Cambodia).

Pyrops watanabei (Matsumura, 1913)

Figs 4, 8, 16-22

Fulgora (Hotinus) watanabei Matsumura, 1913: 54 [described; close to "Fulgora ponderosus" (Stål, 1854)], pl. 8, fig. 1 [habitus illustrated] (types in HUIC).

Fulgora chimara Schumacher, 1915a: 129 [described] (Types in MFNB and SDEI) [synonymized by Kato (1928); reinstated as good species by Metcalf (1947); re-synonymized by Lallemand (1963)].

Fulgora watanabei var. apicalis Kato, 1928: 221 [described; host plant], pl. 9, fig. 1 [habitus illustrated] (type in UMUT). syn. nov. [name preoccupied by Fulgora apicalis Westwood, 1838, replaced by F. watanabei var. formosana by Metcalf (1947)].

Fulgora watanabei var. formosana Metcalf, 1947: 208 [replacement name for F. watanabei var. apicalis]. syn. nov.

Fulgora chimara - Schumacher 1915b: 110 [listed from "Formosa" (= Taiwan)]. — Kato 1928: 221 [synonymized under Pyrops watanabei (Matsumura, 1913)]. - Metcalf 1947: 193 [catalogued as a good species]. — Lallemand 1963: 89 [synonymized under Pyrops watanabei (Matsumura, 1913)].

Fulgora watanabei - Kato 1928: 221 [listed; senior synonym of Fulgora chimara Schumacher, 1915; host plant]. - Mutsumura 1931: 1267 [described; illustrated]. — Chou et al. 1985: 118 [described; mentioned from Taiwan and China (Guangxi, Guangdong and Hainan)].

Hotinus watanabei - Matsumura 1931: pl. 8, fig. 12 [illustrated].

Pyrops watanabei - Nagai \& Porion 1996: 26 [catalogued; mentioned from China (erroneous)]. Liang \& Suwa 1998: 157 [lectotype designation]. - Yen \& Yang 2001 [description; biology; distribution; protection status]. 


\section{Diagnosis}

The species is immediately recognized by the following combination of characters:

(1) cephalic process yellow and inflated apically (Fig. 4D-E).

(2) abdomen red ventrally (Fig. 4B).

(3) tegmina mainly white on disc and with 3 black spots in costal area before nodal line (Fig. 4A).

\section{Etymology}

The species was dedicated to its collector, Kenji Watanabe.

\section{Type material}

TAIWAN: Lectotype, + of Fulgora (Hotinus) watanabei Matsumura, 1913 (examined from photographs, Fig. 16) [Hotinus watanabei Mats.] [Hotinus watanabei Mats.] [Hotinus watanabei det Matsumura] [Formosa Matsumura/underside: Hoppo, $1^{\text {st }}$ VII '07] [Type Matsumura] [Lectotype Fulgora (Hotinus) watanabei Mats. det. A.P. Liang \& M. Suwa 1997] (HUIC).

TAIWAN: Paralectotype, $q$ of Fulgora (Hotinus) watanabei Matsumura, 1913 (examined from photographs, Fig. 17) [Hoppo] [Paralectotype Fulgora (Hotinus) watanabei Mats. det. A.P. Liang \& M. Suwa 1997] (HUIC).

TAIWAN: Paralectotype, $q$ of Fulgora (Hotinus) watanabei Matsumura, 1913 (examined from photographs, Fig. 18) [Formosa Matsumura /underside: Hoppo, 27 VII '07] [Paralectotype Fulgora (Hotinus) watanabei Mats. det. A.P. Liang \& M. Suwa 1997] (HUIC).

TAIWAN: Syntype, $q$ of Fulgora chimara Schumacher, 1915 (Fig. 19) [Formosa, Hoozan, VIII.10, H. Sauter S.G.] [Fulgora chimara* Schum., F. Schumacher det.] [Type] (MFNB).

TAIWAN: Syntype, + of Fulgora chimara Schumacher, 1915 (examined from photographs, Fig. 20) [Kosempo, Formosa, H. Sauter, VII. \#.1911] [Fulgora chimara * Schum., F. Schumacher det.] [Syntypus] (SDEI).

TAIWAN: Holotype, + of Fulgora watanabei var. apicalis Kato, 1928 (examined from photographs, Fig. 21) [Horisha, Formosa (VIII.1919) Col. M. Kato.] [Type No. 95, M. Kato coll.] (UMUT).

\section{Additional material}

TAIWAN: 1 q, Taipei city, Congguan Nat. Taiwan University Campus, 2007, leg. W.B. Yeh (RBINS); 1 ô (dissected), 1 , Taipei, Tanshui, 14 Jun. 2002, J.H. Chen (NMNS).

\section{Material examined from photographs}

TAIWAN: eggs (Fig. 22A), Taipei City, 28 Jul. 2012, S. Chen; eggs (Fig. 22B), idem, 19 Feb. 2016; 1 nymph (Fig. 22C), Nantou County, 14 Feb. 2012, S. Chen; 1 nymph (Fig. 22D): Taipei City, 7 Jun. 2012, on Triadica sebifera, S. Chen; 1 ex. (Fig. 22E-F), idem, 16 Aug. 2012, on Triadica sebifera, S. Chen; 1 ex. (Fig. 22G), idem, predated by a Sparassidae spider; 5 ex. (Fig. 22H), Taipei City, 6 Aug. 2011, on Triadica sebifera, S. Chen.

\section{Measurements and ratios}

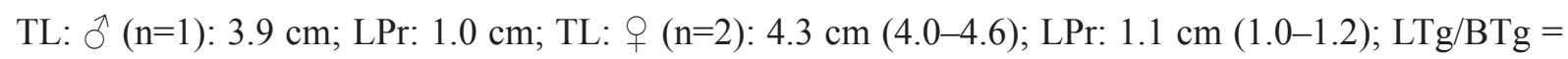
2.31; $\mathrm{BF} / \mathrm{BPrH}=2.53 ; \mathrm{LPr} / \mathrm{LF}=2.82 ; \mathrm{LPr} / \mathrm{BPrH}=2.55$. 


\section{Male genitalia}

Pygofer higher than long, with posterior margin sinuate in lateral view (Fig. 8A). Anal tube slightly elongate, 1.1 times as long as broad in dorsal view, broader at $4 / 5$ of total length (Fig. 8C); lateral margins slightly sinuate and apical margin strongly concave in dorsal view (Fig. 8C). Gonostyli (Fig. 8A) elongate, 1.77 times as long as high in lateral view; dorsal margin regularly and broadly rounded and posterior margin slightly projecting posteriorly in middle in lateral view (Fig. 8A).

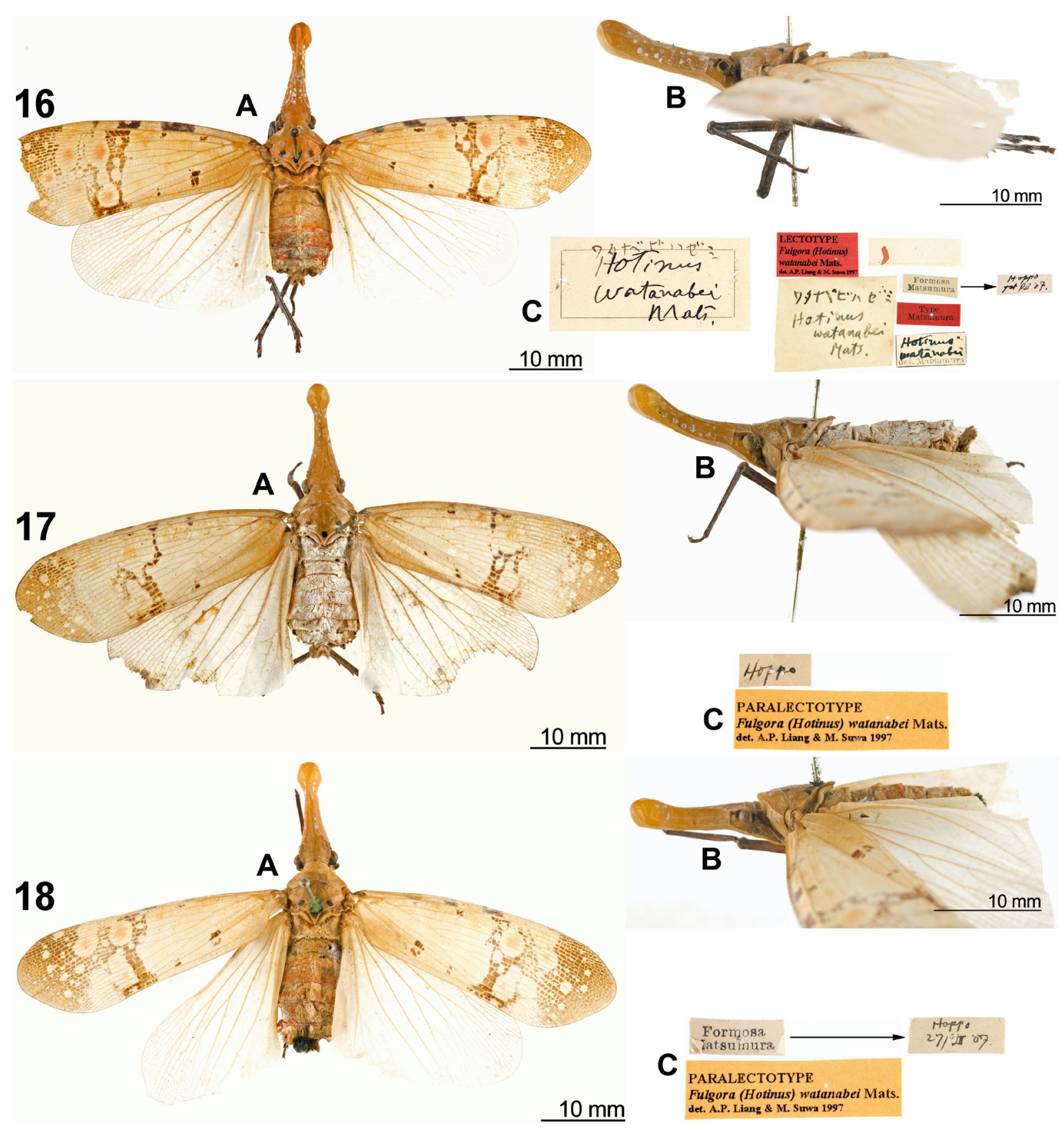

Figs 16-18. Pyrops watanabei (Matsumura, 1913), type specimens of Hotinus watanabei Matsumura, 1913 (photographs by HUIC). 16. Lectotype, ․ - 17. Paralectotype, ㅇ. - 18. Paralectotype, ㅇ. A. Habitus, dorsal view. B. Habitus, left lateral view. C. Labels (arrow indicates the reverse of the label). 

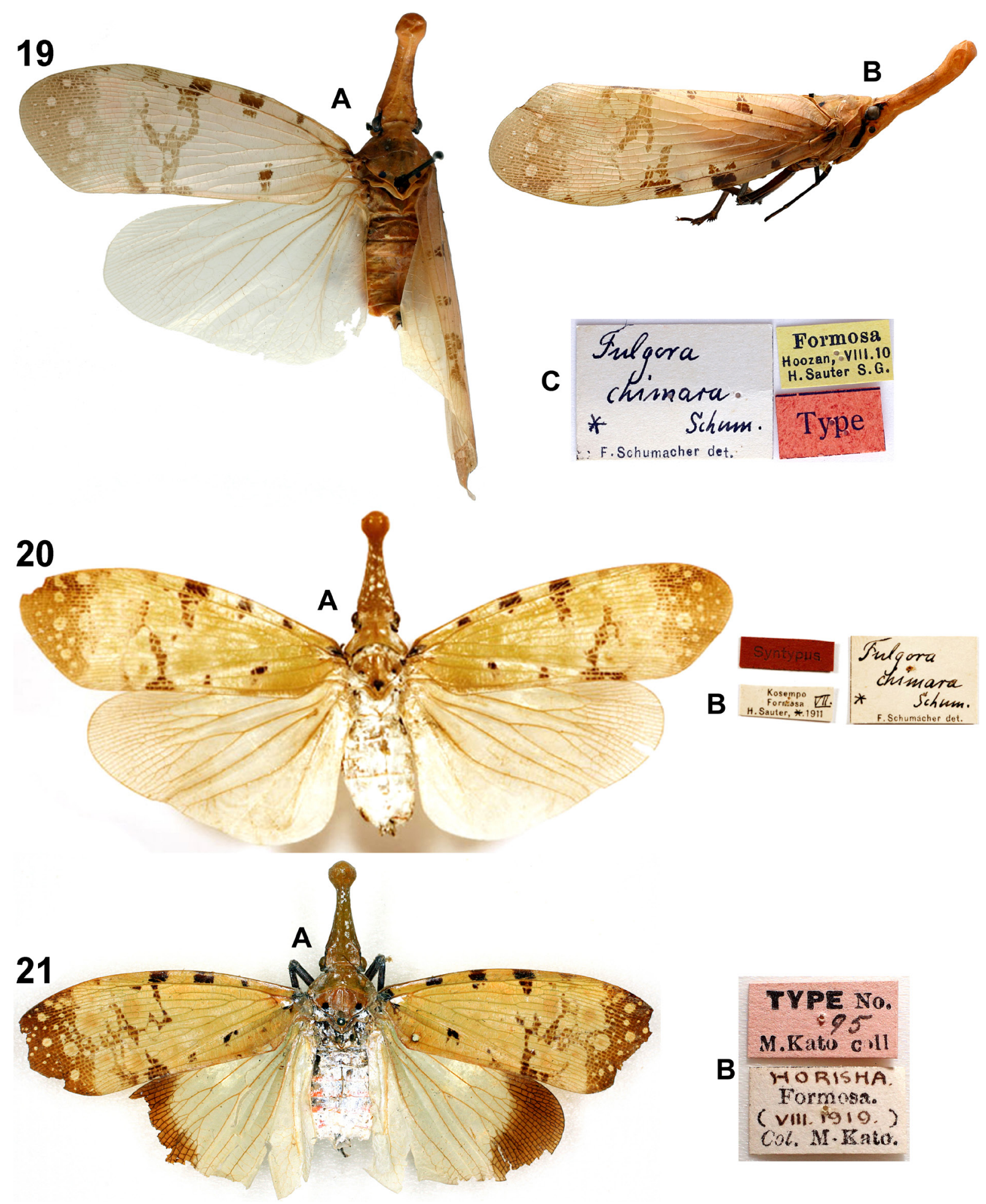

Figs 19-21. Pyrops watanabei (Matsumura, 1913), type specimens of the synonymised taxa. 1920. Fulgora chimara Schumacher, 1915. 19. Lectotype, $q$ (MFNB, photographs by J. Constant). A. Habitus, dorsal view. B. Habitus, right lateral view. C. Labels. Total length: $37 \mathrm{~mm}$. 20. Paralectotype, (photographs SDEI). A. Habitus, dorsal view. B. Labels. Wingspan: $82 \mathrm{~mm}$. - 21. Fulgora watanabei apicalis Kato, 1928, holotype, o (UMUT, photographs by M. Hayashi). A. Habitus, dorsal view. B. Labels. Wingspan: $80 \mathrm{~mm}$. 

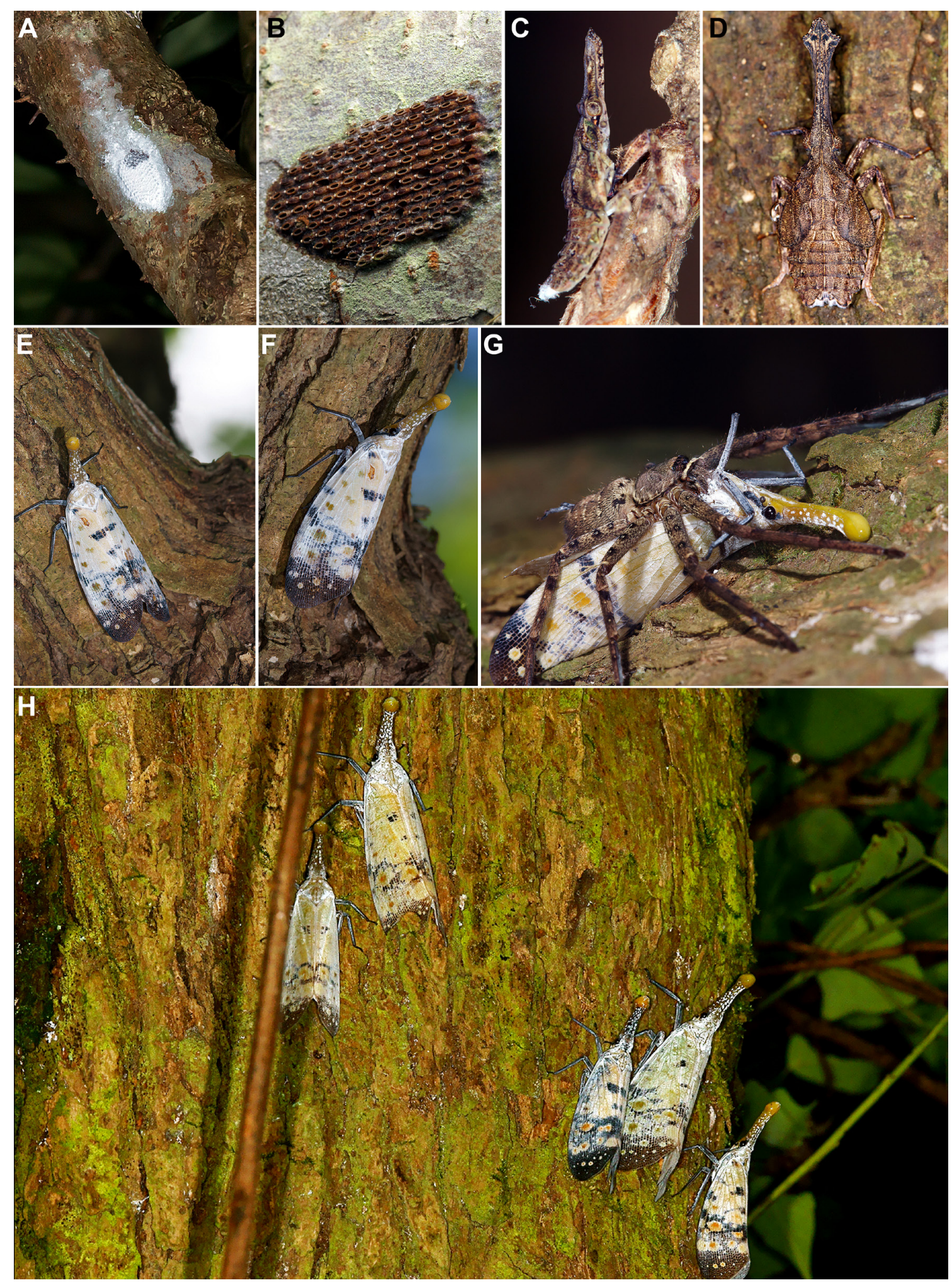

Fig. 22. Pyrops watanabei (Matsumura, 1913) in nature (photographs by S. Chen). A. Eggs, Taipei City, 28 Jul. 2012. B. Hatched eggs, idem, 19 Feb. 2016. C. Nymph, Nantou County, 14 Feb. 2012. D. Nymph, Taipei City, 7 Jun. 2012, on Triadica sebifera (L.). E-F. Adult, Taipei City, 16 Aug. 2012, on T. sebifera. G. Adult predated by a Sparassidae spider, Taipei City, 16 Aug. 2012, on T. sebifera. H. Group of adults, Taipei City, 6 Aug. 2011, on trunk of T. sebifera. 


\section{Biology}

The species was recorded on Triadica sebifera (L.) Small (Euphorbiaceae) by Kato (1928), and on the same tree and Sapium discolor Muell.-Arg. (Euphorbiaceae) by Yen \& Yang (2015). Those data were confirmed by multiple observations in the field; freshly laid eggs were observed at the end of July, nymphs in February and June (pers. comm. S. Chen, Dec. 2015)

\section{Distribution}

Taiwan.

\section{Remarks}

This species was mentioned from China by Chou et al. (1985) and Nagai \& Porion (1996). However, no specimen of $P$. watanabei could be found either in the collections of NWAFU, where Chou and co-authors worked (pers. comm. D. Qin, Jun. 2016), in the collections of IZCAS (pers. comm. Z.S. Song, Jun. 2016), or in the collections of MHNL, and there are also no photographic records available supporting the presence of the species on the continent. Hence, the species is removed from the list of Chinese Fulgoridae and is regarded as endemic in Taiwan.

Like in P. clavatus, this species shows specimens with posterior wings entirely white and others with the apical third black.

\section{Discussion}

Nearly one century after the description of the most recently described species belonging to the clavatus group, a complete revision with a key allowing accurate identification is proposed, with all conclusions supported by relevant illustration of types of all treated taxa.

Although they are very popular and conspicuous insects, and every entomologist is able to recognize a lantern fly at first glance, the taxonomy within the group remains unresolved in many aspects and much work is still to be done (see also Constant (2015) for another example within the genus Pyrops).

Many fundamental aspects of the knowledge of the clavatus group species are still poorly documented, e.g., geographical distribution, host plants, phenology, nymphal development, etc. This work should be done in situ and could be conducted by local students and researchers. Such work might also lead to discoveries like trophobiotic interactions with other animals, which are currently unknown for the species of this group (see also Constant 2015: 19 for examples in the Pyrops effusus group).

\section{Acknowledgments}

We thank Mr Cédric Audibert (MHNL), Mr Max Barclay (BMNH), Dr Stephan Blank (SDEI), Mr Suede Chen (Taiwan), Mr Derek Croucher (BMNH), Dr Jürgen Deckert (MFNB), Dr Masami Hayashi (Japan), Mr Kawin Jiaranaisakul (Thailand), Mr Harold Labrique (MHNL), Mrs Gunvi Lindberg (NHRS), Mrs Panaka Jirasuttayaporn (Thailand), Mr Daozheng Qin (NWAFU), Mr Zhi Shun Song (IZCAS), Mr Amoret Spooner (OUMNH), Dr Rong Rong Wang (IZCAS), Dr Sudhir Singh (NFIC), Mr Mick Webb (BMNH), Dr Masaya Yago (UMUT) and Dr Hiromi Yoshitomi (EUM) for providing access, photographs and/or information on the specimens under their care; Mr Pol Limbourg (RBINS), Dr Patrick Grootaert (RBINS) and Pr Thierry Bourgoin for their support and comments; Mr Hoang Vu Tru (Institute of Ecology and Biological Resources, Hanoi, Vietnam) and Mr Joachim Bresseel (collaborator, RBINS) for their company and friendship during our collecting trips in Vietnam. The authors' collecting trips were supported through a grant issued by the capacity building Programme of the Belgian Global Taxonomic Initiative National Focal Point that runs under the CEBioS programme with financial support from the Belgian Directorate-General for Development Cooperation (DGD). The first author has benefitted from 
funds from the European Union (Synthesys Project - Grant GB-TAF-1642) for a visit to the collection of BMNH and to the collections of NHRS (Synthesys Project - Grant SE-TAF-527), and funds from RBINS and MHNL for a visit to the collections of MHNL.

\section{References}

Adams R.N. 1847. Description of a new species of Fulgora. The Annals and Magazine of Natural History 20: 204-205.

Allnatt G. 2013. Recuration of the Fulgoridae collection at the Manchester Museum. Journal of Natural Science Collections 1: 44-47.

Amyot C. \& Serville J. 1843. Deuxième partie. Homoptères. Homoptera Latr. Histoire Naturelle des Insectes. Hémiptères. Librairie encyclopédique de Roret, Paris. https://doi.org/10.5962/bhl.title.8471

Atkinson E.T. 1885. Notes on Indian Rhynchota. No. 4. Journal and Proceedings of the Asiatic Society of Bengal 54: 127-158.

Baker C.F. 1925. Remarks on certain Indo-Malayan Fulgora, with special reference to Philippine species. Philippine Journal of Science 28: 343-364.

Blanchard E. 1845. Septième ordre les Hémiptères. In: Blanchard E. Histoire des insectes, traitant de leurs moeurs et de leurs métamorphoses en général et comprenant une nouvelle classification fondée sur leurs rapports naturels 2: 424-427. Available from http://biodiversitylibrary.org/page/25155881 [accessed 20 Mar. 2017]

Bourgoin T. 2016. FLOW (Fulgoromorpha Lists on The Web): a World Knowledge Base Dedicated to Fulgoromorpha. V.8, updated [Apr. 2016]. Available from http://hemiptera-databases.org/flow/ [accessed 1 Dec. 2016].

Burmeister H.C.C. 1845. Rhynchota. No. 8. Fam. Fulgorina Gen. Fulgora. In: Burmeister H.C.C. 18381846. Genera Quaedam Insectorum. Iconibus Illustravit et Descripsit 1. Sumtibus. A. Burmeister, Berlin.

Butler A.G. 1874. List of the species of Fulgora, with description of new forms in the collections of the British Museum. Proceedings of the Zoological Society of London 42 (1): 97-102. https://doi. org/10.1111/j.1096-3642.1874.tb02457.x

Chou I., Wang S. \& Huang J. 1985. Priskribo de novaj specioj de Fulgoroedoj el Cinio (Homopteroj: Fulgoroedoj). Entomotaxonomia 7 (1): 29-38.

Constant J. 2004. Révision des Eurybrachidae (I). Le genre Amychodes Karsch, 1895 (Homoptera: Fulgoromorpha: Eurybrachidae). Bulletin de l'Institut royal des Sciences naturelles de Belgique 74: $11-28$.

Constant J. 2015. Review of the effusus group of the lanternfly genus Pyrops Spinola, 1839, with one new species and notes on trophobiosis (Hemiptera: Fulgoromorpha: Fulgoridae). European Journal of Taxonomy 128: 1-23. https://doi.org/10.5852/ejt.2015.128

Constant J. \& Alisto L. 2015. Contribution to the knowledge of some lanternflies of the Philippines (Hemiptera: Fulgoromorpha: Fulgoridae). Belgian Journal of Entomology 27: 1-16.

Constant J., Phauk S. \& Bourgoin T. 2016. Updating lanternflies biodiversity knowledge in Cambodia (Hemiptera: Fulgoromorpha: Fulgoridae) by optimizing field work surveys with citizen science involvement through Facebook networking and data access in FLOW website. Belgian Journal of Entomology 37: 1-16. 
Costa A. 1864. Emitteri in Acquisti fatti durante l'anno 1862. Annuario del Museo Zoologico della R. Università di Napoli. Naples 2: 8-93. Available from http://biodiversitylibrary.org/page/11823135 [accessed 20 Mar. 2017].

Distant W.L. 1906. The Fauna of British India, including Ceylon and Burma. Vol. 3. C.T. Birgham. Taylor \& Francis, London. https://doi.org/10.5962/bhl.title.48423

Distant W.L. 1918. The Homoptera of Indo-China. Annals and Magazine of Natural History (Ser. 9) 1: 196-200.

Duponchel P.A.J. 1840. Essai sur les fulgorelles, par Maximilien Spinola. Revue Zoologique, par la Société cuvierienne; Association Universelle pour l'Advancement de la Zoologie, de l'Anatomie comparée et de la Palaéontologie; Journal mensuel 2: 199-206.

Gadeau de Kerville H. 1881. Insectes Phosphorescents. Léon Deshays, Rouen.

International Commission on Zoological Nomenclature. 1955. Opinion 322. Validation, under the Plenary Powers, of the generic name Fulgora Linnaeus, 1767 (Class lnsecta, Order Hemiptera) and designation for the genus so named of a type species in harmony with current nomenclatorial practice. Opinions and Declarations Rendered by the International Commission on Zoological Nomenclature 9 (13): 185-208.

Kato M. 1928. Notes on some Formosan Homoptera, with descriptions of new genus and species. Kontyu, Tokyo Entomological Society 2: 221-228.

Kirby W.F. 1885. Elementary Text-book of Entomology. W. Swan Sonnenschein \& Co., London https:// doi.org/10.5962/bhl.title. 29217

Kirby W.F. 1892. Elementary Text-book of Entomology. Second edition. W. Swan Sonnenschein \& Co., London. https://doi.org/10.5962/bhl.title.8139

Lallemand V. 1963. Révision des Fulgoridae (Homoptera). Deuxième partie. Faunes asiatique et australienne. Mémoires de l'Institut royal des Sciences naturelles de Belgique (2e série) 75: 1-99.

Liang A.-P. 1998. Nomenclatorial notes on the Oriental lanternfly genus Pyrops Spinola (Hemiptera: Fulgoroidea: Fulgoridae). Acta Zootaxonomica Sinica 23 (1): 41-47.

Liang A.-P. \& Suwa M. 1998. Type specimens of Matsumura's species of Fulgoroidea (excluding Delphacidae) in the Hokkaido University collection, Japan (Hemiptera: Fulgoromorpha). Insecta Matsumurana, Series Entomology, New Series 54: 133-166.

Matsumura S. 1913. Thousand Insects of Japan Additamenta. Vol. 1. Keiseisha, Tokyo [in Japanese].

Matsumura S. 1931. 6000 Illustrated Insects of Japan Empire. Tokoshoin, Tokyo [in Japanese].

Metcalf Z.P. 1947. General Catalogue of the Homoptera. Fascicle IV Fulgoroidea. Part 9 Fulgoridae. North Carolina State College, Raleigh (U.S.A.).

Nagai S. \& Porion T. 1996. Fulgoridae 2: Catalogue illustré des Faunes asiatique et australienne. Sciences Nat, Compiègne.

Ollenbach O.C. 1929. Part 3. New species of Cicadidae and Fulgoridae from India and Burma (Hemip.). Indian Forest Records 13 (6): 271-282.

Paiva C.A. 1919. XXIII. Rhynchota from the Garo Hills, Assam. Records of the Indian Museum 16: 349-377. Available from http://biodiversitylibrary.org/page/11132445 [accessed 23 Feb. 2017].

Satô M. \& Nagai S. 1994. Taxonomic notes on the Southeast Asian species of the genus Fulgora (Homoptera: Fulgoridae). Transactions of the Shikoku Entomological Society 20 (3-4): 307-314. 
Schaum H.R. 1850. Fulgorellae. Erster Section A-G. In: Ersch I.S. \& Gruber I.G. (eds) Allgemeine Encyklopädie der Wissenschaften und Künste in alphabetischer Folge von genannten Schriftstellern bearbeitet und herausgegeben. Brockhaus Verlag, Mannheim.

Schmidt E. 1905. Beitrag zur Kenntnis der Fulgoriden. II. Die im Stettiner Museum vorhandenen Arten des Genus Fulgora Linné. Entomologische Zeitung, herausgegeben von dem entomologischen Vereine zu Stettin 66: 342-357.

Schumacher F. 1915. Homoptera in H. Sauter's Formosa-Ausbeute. Supplementa Entomologica 4: 108142.

Spinola M. 1839. Essai sur les Fulgorelles, sous-tribu de la tribu des Cicadaires, ordre des Rhyngotes. Annales de la Société Entomologique de France 8: 133-337. Available from http://biodiversitylibrary. org/page/33710046 [accessed 17 Mar. 2017]

Stål C. 1854. Nya Hemiptera. Ofversigt af Kongliga Svenska Vetenskaps-Akademiens Förhandlingar 11: $231-255$.

Urban J. \& Cryan J. 2009. Entomologically famous, evolutionarily unexplored: the first phylogeny of the lanternfly family Fulgoridae (Insecta: Hemiptera: Fulgoroidea). Molecular Phylogenetics and Evolution 50: 471-484. https://doi.org/10.1016/j.ympev.2008.12.004

Walker F. 1851. List of the Specimens of Homopterous Insects in the Collection of the British Museum. Vol. 2: 261-636. British Museum, London.

Walker F. 1858. Supplement. List of the Specimens of Homopterous Insects in the Collection of the British Museum. British Museum, London.

Westwood J.O. 1839. On the family Fulgoridae, with a monograph of the genus Fulgora of Linnaeus. The Transactions of the Linnean Society of London, Second series, Zoology 18: 133-153.

Westwood J.O. 1848. The Cabinet of Oriental Entomology. Vol. 4. W. Smith, London.

Yen S.-H. \& Yang P.-S. 2001. Illustrated Identification Guide to Insects Protected by the CITES and Wildlife Conservation Law of Taiwan, R.O.C. Council of Agriculture, Executive Yuan, Taiwan, R.O.C. Available from http://subject.forest.gov.tw/books/book_03e/insect_93.htm [accessed 12 Dec. 2015].

Manuscript received: 19 July 2016

Manuscript accepted: 27 January 2017

Published on: 27 March 2017

Topic editor: Gavin Broad

Desk editor: Kristiaan Hoedemakers

Printed versions of all papers are also deposited in the libraries of the institutes that are members of the EJT consortium: Muséum national d'Histoire naturelle, Paris, France; Botanic Garden Meise, Belgium; Royal Museum for Central Africa, Tervuren, Belgium; Natural History Museum, London, United Kingdom; Royal Belgian Institute of Natural Sciences, Brussels, Belgium; Natural History Museum of Denmark, Copenhagen, Denmark; Naturalis Biodiversity Center, Leiden, the Netherlands. 